\title{
Revisiting Jatropha curcas Monomeric Esterase: A Dienelactone Hydrolase Compatible with the Electrostatic Catapult Model
}

\author{
Marcos Gustavo Araujo Schwarz ${ }^{1, *(\mathbb{D})}$, Deborah Antunes ${ }^{1}\left(\mathbb{D}\right.$, Gabriela Coelho Brêda ${ }^{2}$, Richard Hemmi Valente ${ }^{3(\mathbb{C})}$ \\ and Denise Maria Guimarães Freire 4 (i) \\ 1 Laboratório de Genômica Funcional e Bioinformática, Instituto Oswaldo Cruz, Fiocruz, \\ Rio de Janeiro 21040900, Brazil; deborah.santos@fiocruz.br \\ 2 Laboratório de Microbiologia Molecular e Proteínas, Departamento de Bioquímica, Instituto de Química, \\ Universidade Federal do Rio de Janeiro, Rio de Janeiro 21941909, Brazil; breda.gabriela@gmail.com \\ 3 Laboratório de Toxinologia, Instituto Oswaldo Cruz, Fiocruz, Rio de Janeiro 21040900, Brazil; \\ richardhemmi@gmail.com \\ 4 Laboratório de Biotecnologia Microbiana, Departamento de Bioquímica, Instituto de Química, Universidade \\ Federal do Rio de Janeiro, Rio de Janeiro 21941909, Brazil; freire@iq.ufrj.br \\ * Correspondence: schwarz@ioc.fiocruz.br; Tel.: +55-21-38658201
}

Citation: Schwarz, M.G.A.; Antunes, D.; Brêda, G.C.; Valente, R.H.; Freire, D.M.G. Revisiting Jatropha curcas Monomeric Esterase: A Dienelactone Hydrolase Compatible with the Electrostatic Catapult Model. Biomolecules 2021, 11, 1486. https:// doi.org/10.3390/biom11101486

Academic Editor: Umesh R. Desai

Received: 27 July 2021

Accepted: 11 August 2021

Published: 9 October 2021

Publisher's Note: MDPI stays neutral with regard to jurisdictional claims in published maps and institutional affiliations.

Copyright: (c) 2021 by the authors. Licensee MDPI, Basel, Switzerland. This article is an open access article distributed under the terms and conditions of the Creative Commons Attribution (CC BY) license (https:/ / creativecommons.org/licenses/by/ $4.0 /)$.

\begin{abstract}
Jatropha curcas contains seeds with a high oil content, suitable for biodiesel production After oil extraction, the remaining mass can be a rich source of enzymes. However, data from the literature describing physicochemical characteristics for a monomeric esterase from the J. curcas seed did not fit the electrostatic catapult model for esterases/lipases. We decided to reevaluate this J. curcas esterase and extend its characterization to check this apparent discrepancy and gain insights into the enzyme's potential as a biocatalyst. After anion exchange chromatography and two-dimensional gel electrophoresis, we identified the enzyme as belonging to the dienelactone hydrolase family, characterized by a cysteine as the nucleophile in the catalytic triad. The enzyme displayed a basic optimum hydrolysis $\mathrm{pH}$ of 9.0 and an acidic $\mathrm{pI}$ range, in contrast to literature data, making it well in line with the electrostatic catapult model. Furthermore, the enzyme showed low hydrolysis activity in an organic solvent-containing medium (isopropanol, acetonitrile, and ethanol), which reverted when recovering in an aqueous reaction mixture. This enzyme can be a valuable tool for hydrolysis reactions of short-chain esters, useful for pharmaceutical intermediates synthesis, due to both its high hydrolytic rate in basic $\mathrm{pH}$ and its stability in an organic solvent.
\end{abstract}

Keywords: Jatropha curcas L.; seed; esterase; dienelactone hydrolase

\section{Introduction}

Jatropha curcas (physic nut) — a plant belonging to the Euphorbiaceae family-has received attention from the scientific community due to its potential in the biodiesel production field [1]. Biofuel generation can be achieved through different methods such as the alkaline transesterification of the seed oil triglycerides with short-chain alcohol (usually methanol or ethanol) [2]. Such technology is quite advantageous due to the good quality of the produced biodiesel. Furthermore, J. curcas can be cultivated on nutrient-poor soils, thus not competing with other crops of agricultural importance [3].

Along with the biodiesel purpose, interest has arisen concerning the remaining material after the oil extraction, known as the press cake, mainly to use it as animal food due to its high protein content [4]. One drawback of such an approach is the presence of different toxic substances in this material, with phorbol esters being the most harmful for animals [5]. That is why non-toxic J. curcas strains are used for animal feeding purposes. However, this material can also be a source of several enzymes with interesting features. Such is the case for the previously described J. curcas lipase, isolated from the press cake and used in a hybrid (enzymatic/chemical) hydroesterification process for biodiesel production [6]. 
Several studies focusing on the characterization of proteins/enzymes from the J. curcas press cake have been published [7,8]. Furthermore, peptidase [9] and esterases/lipases [10-12] have been studied. Esterases and lipases are enzymes belonging to the $\alpha / \beta$-hydrolase fold family that generally act on the ester bond of different compounds. Besides hydrolysis, when a low water content medium, such as an alcohol, and an acyl donor are provided, these enzymes can also catalyze esters' synthesis by different reactions. Esterases/lipases are sometimes organized into subgroups according to their preferred substrate (e.g., triacylglycerol lipases (E.C. 3.1.1.3), phospholipases (E.C. 3.1.1.4), and dienelactone hydrolases (E.C. 3.1.1.45)) [13,14] Moreover, esterases typically act on water-soluble esters, whereas lipases act at the water/oil interface on "water-insoluble" esters that form micelles in aqueous systems [15]. These enzymes may be used at an industrial scale for several purposes such as for the kinetic racemic resolution of pharmaceutical chiral compounds, as some of these proteins are regio, stereo, and enantioselective catalysts [16].

Regarding J. curcas seed esterases, two enzymes with this activity have been described as present in the non-germinated seed: one monomeric (form $\mathrm{B}$ ) and the other a multimer (form A). In addition, the induction of an enzyme with lipolytic activity occurs during germination. Unlike other esterases/lipases, published data on J. curcas monomeric esterase reported $\mathrm{pI}$ and optimal hydrolysis $\mathrm{pH}$ values that did not fit the widely accepted "electrostatic catapult" model [10], which describes a relevant feature of the esterase/lipase group mechanism of action; in this model, the pI value of the enzyme is usually acidic and therefore lower than the optimal hydrolysis $\mathrm{pH}$ value. Furthermore, the model predicts this enzyme group to display higher hydrolytic activity at basic $\mathrm{pH}$ due to the negative surface potential surrounding the enzyme active site, repelling one of the final reaction products, namely the carboxylic acid (negatively charged in the neutral and basic $\mathrm{pH}$ range) $[17,18]$. Finally, an important point to consider is that these J. curcas enzymes have characteristics of interest to the industry, such as stability and high hydrolytic activity in basic $\mathrm{pH}$ conditions [10].

This work aimed to explore the potential of J. curcas monomeric esterase as a biocatalyst and better understand how this enzyme could work outside the electrostatic catapult model. Departing from non-germinated seeds, we revisited the enzyme's purification (albeit partial) and physicochemical characterization and performed protein identification by mass spectrometry. After protein fractionation, the enzyme present in the enriched fraction was identified as belonging to the dienelactone hydrolase family, with an acidic $\mathrm{pI}$ and a basic optimum hydrolysis $\mathrm{pH}$; the former contrasts the literature [10] but fit the electrostatic catapult model together with our structural analysis. Moreover, the enzyme is inhibited by divalent cations and is almost inactive in an organic solvent, but not irreversibly. Altogether, our data show that this enzyme may be a valuable tool in hydrolysis reactions with short-chain esters for pharmaceutical intermediates synthesis, for example.

\section{Materials and Methods}

\subsection{Crude Enzyme Extract Preparation and Ethanol Precipitation}

J. curcas L. seeds were obtained from DSMM/CATI (Departamento de Sementes, Mudas e Matrizes/Coordenadoria de Assitência Técnica Integral), Águas de Santa Bárbara, São Paulo, Brazil. They were kept under vacuum at $4{ }^{\circ} \mathrm{C}$ until processing. Before extraction, dormant seeds were dehulled and albumen was used for acetone powder preparation. Briefly, $200 \mathrm{~mL}$ of ice-cold acetone was added to $100 \mathrm{~g}$ of albumen and the solid material was ground and further washed with acetone twice. This material was stored at $4{ }^{\circ} \mathrm{C}$ until usage.

Proteins were extracted from the seed acetone powder with $0.1 \mathrm{M}$ Tris-HCl pH 7.5 for $1 \mathrm{~h}$. After centrifugation at $16,000 \times \mathrm{g}$ for $20 \mathrm{~min}$, proteins from clarified supernatant were fractionated by ethanol differential precipitation as described by [10]. The first fraction was obtained at $50 \%$ of ethanol saturation, followed by centrifugation. Ethanol was added to the remaining supernatant to reach $80 \%$ saturation and the material was recovered by centrifugation. Both fractions were resuspended in water and further lyophilized. 


\subsection{Anion Exchange Chromatography}

The $50-80 \%$ ethanol saturation fraction $(50-80 \% \mathrm{EtOH})$ was submitted to anion exchange chromatography. The Akta Purifier system (G.E. Healthcare, Uppsala, Sweden) was used at room temperature with the Mono Q 5/50 GL $1 \mathrm{~mL}$ column (G.E. Healthcare) and a constant flow rate of $0.5 \mathrm{~mL} / \mathrm{min}$. After sample injection, elution was performed with a linear gradient from 0 to $40 \%$ of the elution mobile phase in 40 -column volumes. The equilibration mobile phase was $20 \mathrm{mM}$ Tris- $\mathrm{HCl} \mathrm{pH} 7.5$ and the elution mobile phase composition was the same as the equilibration plus $1 \mathrm{M} \mathrm{NaCl}$. Fractions of $0.5 \mathrm{~mL}$ were each automatically collected throughout the elution step and further analyzed.

\subsection{Enzyme Activity Assays}

\subsubsection{Esterase}

All esterase activity assays were performed using p-nitrophenyl butyrate as a substrate (final concentration of $1 \mathrm{mM}$ ) in $0.1 \mathrm{M}$ Tris- $\mathrm{HCl}$ buffer $(\mathrm{pH} 7.5)$ at room temperature, except when analyzing enzyme chain-length specificity, for which we also used acetate, propionate, laurate, and palmitate p-nitrophenyl esters. Product release was accompanied by spectrophotometry (ThermoFisher Scientific, Woodlands, Singapore) analysis at $348 \mathrm{~nm}$. One international esterase unity $(\mathrm{U})$ was defined as the enzyme amount that released $1 \mu \mathrm{mol}$ of p-nitrophenol per minute at the assay conditions.

Activity in the presence of divalent ions $\left(\mathrm{Ca}^{2+}, \mathrm{Co}^{2+}, \mathrm{Mg}^{2+}\right.$, and $\mathrm{Ba}^{2+}$ as their respective chloride salts at the final concentration of $10 \mathrm{mM}$ ), solvents (isopropanol, acetonitrile, and ethanol at the final concentrations of $10 \%, 20 \%, 40 \%$, and $60 \% v / v)$, and different esterase/peptidase inhibitors ( $1 \mathrm{mM} 4$-amidinophenylmethylsulfonyl fluoride (APMSF), $1 \mathrm{mM}$ iodoacetamide, $10 \mathrm{mM}$ ethylenediaminetetraacetic acid (EDTA), $10 \mu \mathrm{M} \mathrm{E}-64,10 \mu \mathrm{M}$ pepstatin, and $10 \mathrm{mM}$ ortho-phenanthroline) were assessed by adding the different substances into the reaction mixture. For the divalent ions' assays, enzyme activity was also measured in the presence of each salt with $10 \mathrm{mM}$ EDTA.

We also assessed the esterase activity after sample incubation with $10 \%$ and $40 \% v / v$ isopropanol or acetonitrile for $30 \mathrm{~min}$ at room temperature, as well as the recovery in an aqueous reaction mixture (0.1 $\mathrm{M}$ Tris- $\mathrm{HCl}$ buffer $\mathrm{pH} 7.5)$.

\subsubsection{Peptidase}

Peptidase activity was measured using a modified azocasein protocol. Initially, $50 \mu \mathrm{L}$ of the sample was added to a reaction mixture containing $0.2 \%(w / v)$ azocasein and $10 \mathrm{mM} \mathrm{CaCl}_{2}$, obtaining a final volume of $500 \mu \mathrm{L}$. After incubation at $37^{\circ} \mathrm{C}$ for $1 \mathrm{~h}$, the reaction was stopped by the addition of trichloroacetic acid to a final concentration of $7.5 \% w / v$. The absorbance reading at $380 \mathrm{~nm}$ was performed after the addition of $\mathrm{NaOH}$ (final concentration $=0.25 \mathrm{M}$ ). Jararhagin, a metalloendopeptidase isolated from Bothrops jararaca snake venom [19], was used as a positive control.

\subsection{Polyacrylamide Gel Electrophoresis (PAGE)}

\subsubsection{Unidimensional SDS-PAGE}

The protein sample complexity was assessed by polyacrylamide gel electrophoresis under denaturant and reducing conditions as described by [20]. Proteins were separated on $15 \% \mathrm{~T}$ gel at a constant voltage of $200 \mathrm{~V}$ for $45 \mathrm{~min}$ using a Mini-Protean II system (Bio-Rad Laboratories Inc., Hercules, CA, USA). Staining was performed using the Coomassie Blue R-250 protocol [21].

\subsubsection{D SDS-PAGE}

Isoelectrofocusing was performed on strips with immobilized $3.0-10.0 \mathrm{pH}$ gradient (GE Healthcare). Briefly, $130 \mu \mathrm{g}$ of protein resuspended in a rehydration buffer ( $7 \mathrm{M}$ urea, $2 \mathrm{M}$ thiourea, and $4 \% w / v$ CHAPS) was added to $150 \mu \mathrm{L}$ of a solution containing ampholyte 3-10 $(10 \mu \mathrm{L} / \mathrm{mL})$, DeStreak $(12 \mu \mathrm{L} / \mathrm{mL})$, and $5 \mathrm{mM}$ Tris. Focusing parameters were: active 
rehydration ( $30 \mathrm{~V}$ ) for $12 \mathrm{~h}$; $200 \mathrm{~V}$ for $1 \mathrm{~h} ; 500 \mathrm{~V}$ for $1 \mathrm{~h}$; $1000 \mathrm{~V}$ for $1 \mathrm{~h}$; linear gradient from 1000-3500 V over $30 \mathrm{~min}$; and $3500 \mathrm{~V}$ until 24,000 Vh were achieved.

After focusing, the strip was treated with $10 \mathrm{mg} / \mathrm{mL}$ DTT, followed by $20 \mathrm{mg} / \mathrm{mL}$ iodoacetamide incubation, both for $15 \mathrm{~min}$. The second dimension occurred on $15 \% \mathrm{~T}$ SDS-PAGE at constant current (2.5 mA per gel) for $30 \mathrm{~min}$, followed by $5 \mathrm{~mA}$ per gel, until the tracking dye left the gel. The gel was stained with the colloidal Coomassie Brilliant Blue G-250 protocol [21].

\subsubsection{Esterase Zymography}

Samples were loaded in native 15\% T PAGE (without SDS and 2-mercaptoethanol) and ran at a constant voltage of $100 \mathrm{~V}$. After this step, the gel was incubated in $0.05 \%(w / v)$ Fast Blue R.R. solution in 0.1 M phosphate buffer $(\mathrm{pH} 6.2)$ with $0.02 \%(w / v) \alpha$-naphthyl acetate until band development.

\subsection{Protein Digestion, Peptide Extraction, and Mass Spectrometry Analysis}

Desired protein spots/bands were excised and in-gel protein digestion was performed based on $[22,23]$ with modifications. Briefly, protein spots/bands were washed three times with $50 \%(v / v)$ acetonitrile in $25 \mathrm{mM}$ ammonium bicarbonate $\mathrm{pH}$ 8.0, dehydrated in acetonitrile, and dried in a vacuum centrifuge. For bands derived from unidimensional SDS-PAGE, gel pieces were previously reduced with $65 \mathrm{mM}$ DTT, alkylated with $200 \mathrm{mM}$ iodoacetamide, washed with $100 \mathrm{mM}$ ammonium bicarbonate, and dehydrated with acetonitrile. Gel pieces from both 2D and 1D-SDS-PAGE were rehydrated in $40 \mathrm{mM}$ ammonium bicarbonate containing $20 \mathrm{ng} / \mu \mathrm{L}$ of sequencing grade modified trypsin. Digestion was performed for $16 \mathrm{~h}$ at $37^{\circ} \mathrm{C}$. The supernatant was recovered and the remaining peptides were extracted from the gel piece upon $5 \%(v / v)$ formic acid in $50 \%(v / v)$ acetonitrile incubation, followed by sonication. This step was repeated once. The peptide solution was desalted/concentrated using C18 tip-column (ZipTip), following the manufacturer's protocol.

Desalted peptides were analyzed by MALDI-TOF/TOF (AB SCIEX TOF/TOF 5800) mass spectrometry in reflectron mode. Samples were mixed onto a MALDI plate in a 1:1 ratio with a proper matrix solution $(10 \mathrm{mg} / \mathrm{mL}$ of $\alpha$-cyano-4-hydroxycinnamic acid in $50 \% v / v$ acetonitrile and $0.3 \% v / v$ trifluoroacetic acid) according to the dried-droplet methodology. The following peptide mixture was used as an external calibration: Argbradykinin $(m / z$ 904.46), angiotensin I $(m / z$ 1296.68), Glu-fibrinopeptide B $(m / z$ 1570.67), ACTH-(1-17) $(m / z$ 2093.08), and ACTH-(18-39) $(m / z$ 2465.19). The ten most intense ions from the M.S. analysis were further analyzed in the MS/MS mode, in which fragment-ions were generated by the post-source decay (PSD) process.

Spectral data were analyzed using the PEAKS software (version 5.3), initially by the de novo tool. Error tolerances of $50 \mathrm{ppm}$ and $0.3 \mathrm{Da}$ were used for the precursor and fragment ions, respectively. Semi-tryptic digestion and two missed cleavages were allowed during the search. We also used variable modifications: cysteine (+57.02 Dacarbamidomethylation; +71.04 - propionamide) and methionine, histidine, and tryptophan (+15.99-oxidation). Further analysis using the PEAKS DB tool was performed, allowing for variable modifications in cysteine (+57.02 Da). All analyses were done using the nonredundant (N.R.) public NCBI databank into the Eukarya taxon. The false discovery rate was estimated using decoy sequences. Finally, a search was done using the PTM FINDER tool, allowing for variable modification in methionine, histidine, and tryptophan (+15.99 Da-oxidation); serine, threonine, and tyrosine (+79.99 Da-phosphorylation); and N-terminal acetylation of peptides $(+42.01 \mathrm{Da})$, dehydration $(-18.01 \mathrm{Da})$ and deamidation $(+0.98 \mathrm{Da})$. Only results with a false discovery rate (FDR) lower than $1 \%$ were reported.

\subsection{Hydrolysis of Racemic 1,2-O-Isopropylidene Glycerol (IPG) Ester and Diethyl Phenylmalonate}

To perform an initial assessment of the J. curcas DLH potential in hydrolysis reactions, we tested the enzyme for the racemic resolution of a chiral and a prochiral compound, namely IPG-octanoate (also known as solketal-C8) and diethyl phenylmalonate, respec- 
tively. In all reactions, we used the $50-80 \% \mathrm{EtOH}$ fraction (amount corresponding to $1 \mathrm{U}$ relative to p-nitrophenyl butyrate).

For IPG-octanoate, reaction and analysis were performed as described in [24] with minor modifications. Briefly, hydrolysis was carried out in screw-capped tubes containing $6 \mathrm{~mL}$ of $50 \mathrm{mM}$ sodium phosphate buffer at $\mathrm{pH} 7.0$ and $1 \mathrm{U}$ of the enzyme. The reactions were initiated by adding $10 \mu \mathrm{L}$ of pure IPG-octanoate and the tubes were incubated in a thermostatized reactor (Amersham Biosciences, Freiburg, Germany) $\left(40^{\circ} \mathrm{C}\right)$. Samples were taken at different time points and both enantiomeric excess (ee) and conversion $(\mathrm{X})$ values were determined by gas chromatography on a CHROMPACK CP 9000 (hydrogen flame ionization detector) with a chiral capillary column (Hydrodex- $\beta-6 \mathrm{TBDM})$.

For diethyl phenylmalonate, the reaction was carried out in screw-capped tubes containing $2.5 \mathrm{~mL}$ of $100 \mathrm{mM}$ sodium phosphate buffer at $\mathrm{pH} 7.0$ and $1 \mathrm{U}$ of the enzyme. The reactions were initiated by adding the substrate (final concentration of $1 \mathrm{mM}$ ) and the tubes were incubated in a thermostatized reactor $\left(40^{\circ} \mathrm{C}\right)$. Samples were taken at different time points and conversion values were determined as described in [25] with minor modifications. Analysis was performed by high-performance liquid chromatography (HPLC) (Spectra Physic SP 100, Stahnsdorf, Germany) using a Kromasil C18 column. Compounds were isocratically eluted (flow rate of $1.0 \mathrm{~mL} / \mathrm{min}$ ) with acetonitrile $/ 20 \mathrm{mM}$ ammonium phosphate $(40: 60 \mathrm{v} / \mathrm{v}) \mathrm{pH} 2.6$ as the mobile phase and the online UV detection was performed at $225 \mathrm{~nm}$.

\subsection{Statistical Analysis}

Enzymatic activity results are represented as the mean of a set of three independent experiments with standard deviation (S.D.). For statistical analysis, we performed a oneway ANOVA (analysis of variance) test on GraphPad Prism 5 software.

\subsection{Central Composite Rotational Design (CCRD)}

The evaluation of the optimal $\mathrm{pH}$ and temperature for catalysis was performed by central composite rotational design (CCRD) with four central points using the 50-80\% $\mathrm{EtOH}$ fraction. The assay buffer was $20 \mathrm{mM}$ Tris- $\mathrm{HCl}$, adjusted for the desired $\mathrm{pH}$. Esterase activity was measured as previously described. The Table 1 below presents the variables (factors) and levels studied in this experimental design.

Table 1. Ranges of the factors investigated in the experimental design.

\begin{tabular}{cccccc}
\hline Factor & \multicolumn{5}{c}{ Level } \\
\hline & -1.41 & -1 & 0 & +1 & +1.41 \\
$\mathrm{pH}$ & 7.0 & 7.3 & 8.0 & 8.7 & 9.0 \\
Temperature $\left({ }^{\circ} \mathrm{C}\right)$ & 30 & 33 & 40 & 47 & 50 \\
\hline
\end{tabular}

\subsection{Comparative Modeling and Structural Analyses of J. curcas Esterase}

We performed comparative modeling using the Swiss-Model server [26] with all default input parameters to derive the three-dimensional structure of J. curcas L. esterase B (GenBank accession number KDP24851.1) using the 2.0-angstrom resolution crystal structure of an uncharacterized protein from Escherichia coli O157:H7 str. Sakai (PDB ID: $4 \mathrm{ZV9}$ ) as a template.

The resulting structure was refined using the locPREFMD server [27]. Initial and optimized models were evaluated by the structure assessment tool of the Swiss-Model server. Figures corresponding to the sequence alignment and three-dimensional structures were generated through ALINE software [28] and UCSF Chimera [29] and ChimeraX [30] software, respectively. The electrostatic potential analysis was conducted with the APBS program [31]. The Amber force field charge and radii parameters were assigned using the PDB2PQR server [32], considering the $\mathrm{pH}$ values 5.5, 8.0, and 9.5. 


\section{Results}

\subsection{Initial Processing and Chain-Length Specificity}

Based on a previous work describing esterase/lipase activities in J. curcas seeds [10], we aimed to identify the monomeric protein responsible for one of the esterase activities (named esterase B by those authors), attempting to better understand its features. Repeating the previously described differential ethanol precipitation protocol, we could detect a protein enrichment corresponding to a band around $30 \mathrm{kDa}$ in the $\mathrm{EtOH} 50-80 \%$ fraction for SDS-PAGE (Figure 1A). Aside from that, the esterase zymography PAGE assay also showed enrichment in only one region, in contrast to what was seen in the crude extract (Figure 1B). Enzymatic activity assays with p-nitrophenyl esters confirmed that the $\mathrm{EtOH}$ $50-80 \%$ protein fraction acted better towards short-chain esters, as assigned by its higher activity towards acetate, propionate, and butyrate ester, decreasing with the chain increase (laurate and palmitate esters) (Figure 1C). These compounds were chosen to perform the initial screening on the esterase chain-length specificity, guiding future substrate choice to assess the J. curcas esterase potential as a biocatalyst.
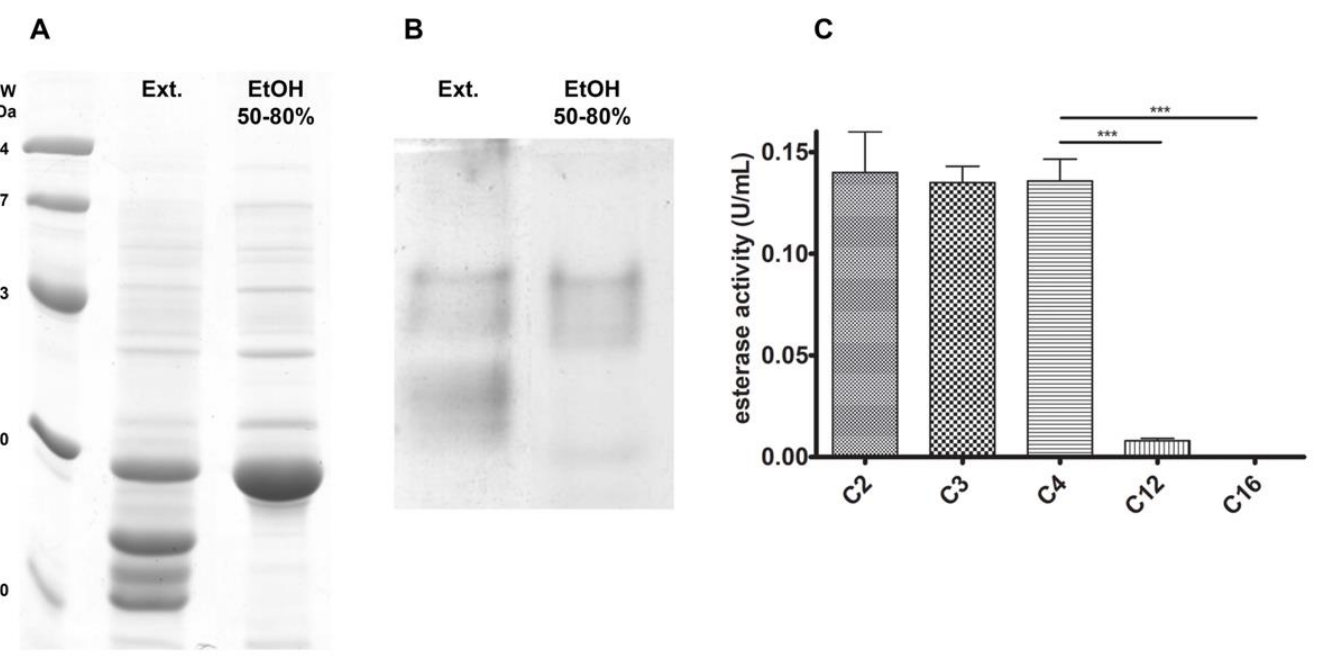

Figure 1. Esterase $B$ enrichment with differential ethanol precipitation. After this fractionation step, the $\mathrm{EtOH} 50-80 \%$ fraction was enriched in a $30 \mathrm{kDa}$ band (A) and a single esterase activity region (B). Chain specificity assay (C) shows that esterase B has greater activity towards short-chain esters, decreasing as chain-length increases. ${ }^{* * *} p<0.001$.

\subsection{J. curcas L. Esterase B Has an Acidic Isoelectric Point and Belongs to the Dienelactone Hydrolase (DLH) Family}

Esterase B was previously characterized as a monomeric protein with higher esterase activity towards short-chain esters and pI 9.0, and with an optimum $\mathrm{pH}$ around 7.5 [10]. With these features, we designed a chromatographic step aimed at a fraction enriched in this protein. Therefore, an anion exchange chromatography was performed with a $\mathrm{pH} 7.5$ buffer. In this situation, most protein molecules should have an overall negative charge, binding to the positively charged resin; however, esterase $\mathrm{B}$ would be expected to exhibit an opposite behavior, eluting in the flow-through. As seen in Figure 2A, there were two prominent peaks in the unbound protein fraction when assessing absorbance at $280 \mathrm{~nm}$ and these pooled fractions were enriched in a $30 \mathrm{kDa}$ protein (Figure 2C). Nevertheless, Figure $2 \mathrm{~B}$ shows that the esterase activity was negligible in the flow-through compared to the activity peak detected along the buffer gradient (as a result, this peak was named "activity peak"). These gradient-eluted fractions were still complex in their protein content, even though they were enriched in three bands around the $30 \mathrm{kDa}$ marker (Figure 2D). 
A

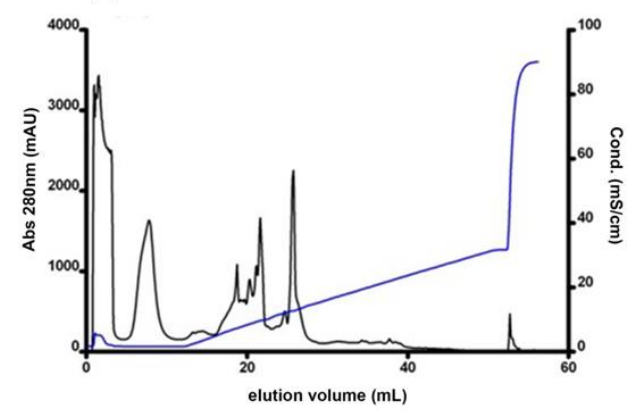

B

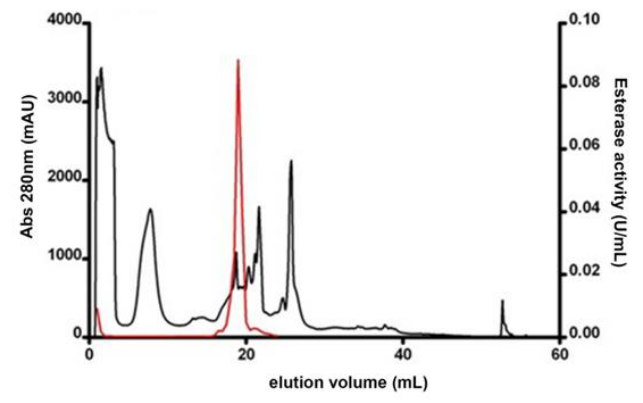

D
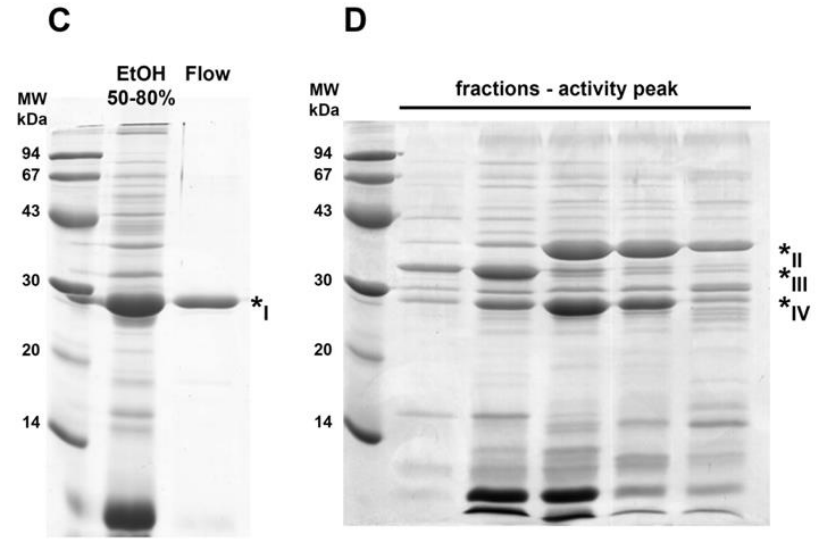

Figure 2. Different esterase B behavior in an anion exchange chromatography. Online absorbance $(280 \mathrm{~nm})$ detection was performed (black curves in $(\mathbf{A}, \mathbf{B}))$ and each sample was further assayed for esterase activity (red curve in (B)). Resin-bound protein elution was performed by a linear gradient of elution buffer (blue curve in (A)). SDS PAGE analysis shows a single observable band in the flow-through fraction (C) and enrichment in three bands around the $30 \mathrm{kDa}$ marker in the activity peak fractions (D). Band numbering corresponds to the MS protein identification data from Table 2.

Protein identification by mass spectrometry analysis of these enriched bands, as shown in Table 2, revealed that the main component of the major band within the chromatography flow-through was curcin $\left({ }^{*} \mathrm{I}\right)$, a common and highly abundant protein found in the J. curcas seed. The three bands within the activity peak were identified as malate dehydrogenase $\left({ }^{*} \mathrm{II}\right)$, lactoylglutathione lyase (* III), and a putative carboxymethylenebutenolidase $\left({ }^{*} \mathrm{IV}\right)$; bands * III and * IV had relative molecular masses closer to the previously identified $30 \mathrm{kDa}$ for esterase B.

We performed a 2D electrophoretic analysis to better physicochemically characterize these samples. We used both the EtOH 50-80\% fraction and the higher esterase activity fraction after the anion exchange chromatography. As seen in Figure $3 \mathrm{~A}$, in the EtOH $50-80 \%$ fraction, we could identify spots corresponding to malate dehydrogenase $\left({ }^{*} 2\right)$, lactoylglutathione lyase $(* 3)$, and the putative carboxymethylenebutenolidase $(* 4)$, the last one having a similar molecular mass as the protein streak towards basic $\mathrm{pH}$ corresponding to curcin (* ${ }^{*}$ ), already known to be a basic protein in the J. curcas seed proteome [33]. We observed that this curcin streak was no longer detected among the proteins within the activity peak after the chromatographic step (Figure 3B). Spot trains seen for regions indicated as $* 2, * 3$, and $* 4$, ranging from $\mathrm{pH}$ 5.0-7.0, indicated that malate dehydrogenase, lactoylglutathione lyase, and carboxymethylenebutenolidase (all proteins enriched in the activity peak; Figure 2D) are present as multiple isoforms. 
Table 2. Protein identification after mass spectrometry analysis. Spots are numbered accordingly to Figures 2 and 3.

\begin{tabular}{|c|c|c|c|c|c|c|c|}
\hline \multirow{2}{*}{ Spot $n^{\circ}$} & \multirow{2}{*}{ Protein } & \multirow{2}{*}{ Organism } & \multirow{2}{*}{$\begin{array}{l}\text { Theoretical Mass } \\
\text { (Da) }\end{array}$} & \multirow{2}{*}{$p$-Value } & \multirow{2}{*}{ Coverage $(\%)$} & \multicolumn{2}{|r|}{ Peptides } \\
\hline & & & & & & $\mathbf{N}$ & Sequence \\
\hline $\mathrm{I} / 1$ & Curcin precursor & Jatropha curcas & $32,514.338$ & $2.42 \times 10^{-224}$ & 24.91 & 5 & $\begin{array}{c}\text { QQTLSFTGSYADFLSR } \\
\text { EAFGFSYSSHEIPVLR } \\
\text { VGGTSYFFNDPESLADAK } \\
\text { SSKPADIAKPLVGFIEMVPEAAR } \\
\text { SSKPADIAKPLVGFIEM(+15.99)VPEAAR }\end{array}$ \\
\hline $\mathrm{II} / 2$ & Malate dehydrogenase & Ricinus communis & $36,103.72$ & $8.3 \times 10^{-149}$ & 22.61 & 4 & $\begin{array}{c}\text { LFGVTTLDVVR } \\
\text { DDLFNINAGIVK } \\
\text { GYVGEDQLGKALEGSDVIIPAGVPR } \\
\text { LNPLVSNLALYDIANTPGVAADVSHINTR }\end{array}$ \\
\hline $\mathrm{III} / 3$ & Lactoylglutathione lyase & Ricinus communis & $31,547.15$ & $2.1 \times 10^{-149}$ & 11.79 & 4 & $\begin{array}{c}\text { FYTEC(+57.02)FGMK } \\
\text { ITSFLDPDGWK } \\
\text { GPTPEPLC(+57.02)QVMLR } \\
\text { GPTPEPLC }(+71.04) Q V M L R\end{array}$ \\
\hline $\mathrm{IV} / 4$ & $\begin{array}{c}\text { Putative car- } \\
\text { boxymethylenebutenolidase }\end{array}$ & Arabidopsis thaliana & $25,893.30$ & $2.4 \times 10^{-59}$ & 12.97 & 2 & $\begin{array}{c}\text { ALIPDLYR } \\
\text { APIQAHFGELDNFVGFSDVTAAK }\end{array}$ \\
\hline
\end{tabular}


A

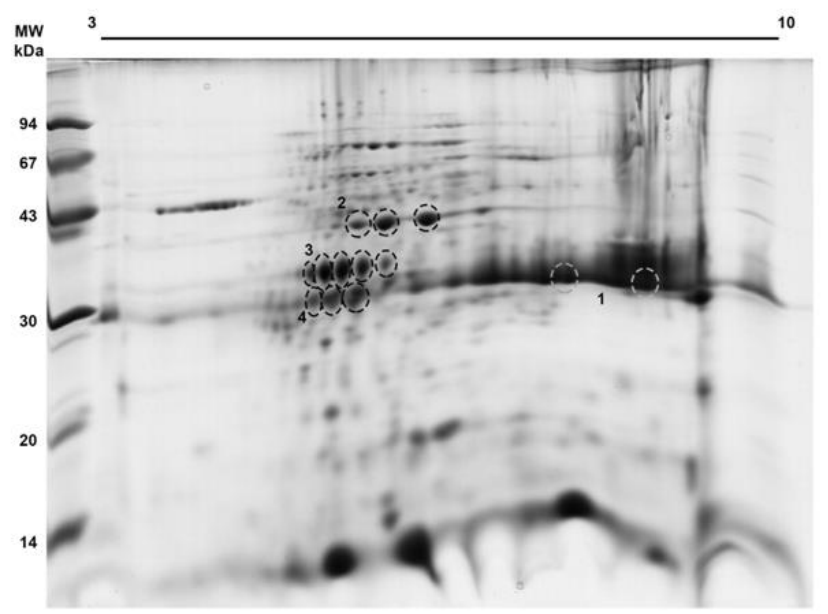

B

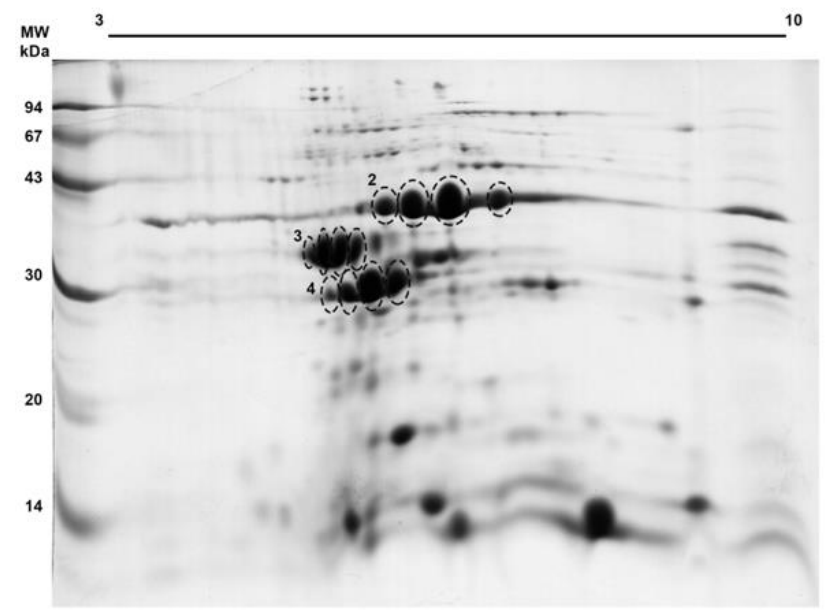

Figure 3. Proteomic profile of the EtOH $50-80 \%$ (A) and activity peak (B) fractions. The indicated spots were processed and peptides were submitted to mass spectrometry for protein identification (Table 2).

Among the three identified proteins, carboxymethylenebutenolidase has been characterized as harboring esterase activity. It is also known that cysteine is used within its catalytic triad as the nucleophile during the catalysis cycle. As seen in Figure 4, APMSF did not affect the $\mathrm{EtOH}$ 50-80\% fraction esterase activity. In contrast, iodoacetamide, an alkylating compound, decreased about $60 \%$ of the original activity compared to the control sample.

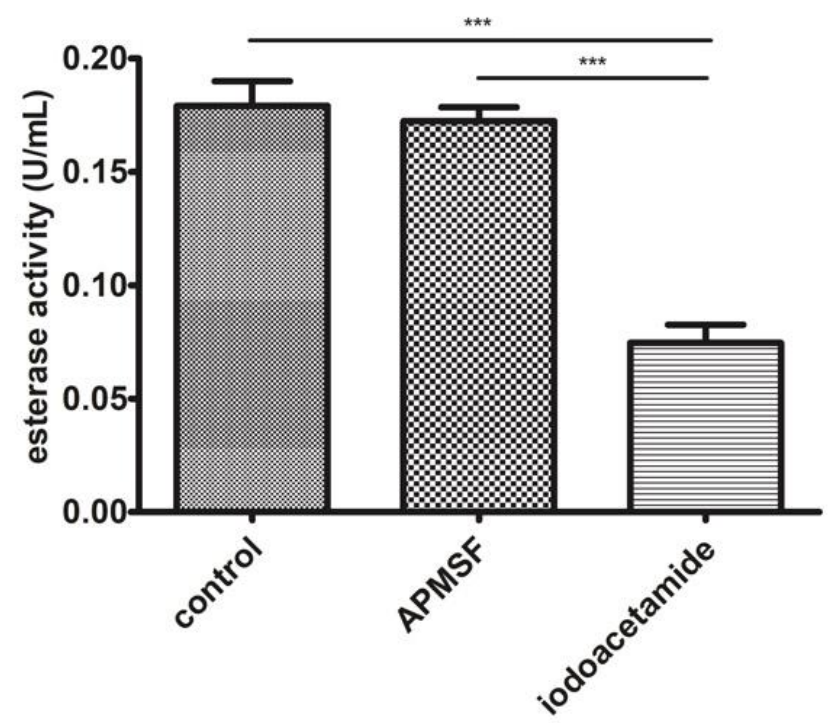

Figure 4. Esterase activity analysis in the EtOH 50-80\% fraction with serine (APMSF) and cysteine (iodoacetamide) esterase inhibitors. ${ }^{* *} p<0.001$.

As seen in Table 2, the identified carboxymethylenebutenolidase (belonging to the dienelactone hydrolase (DLH) family) was from the Arabidopsis thaliana proteome. We performed a Blatsp search to identify its homolog within the J. curcas context. In Figure 5, we can observe that the sequence from J. curcas (GenBank accession number KDP24851.1) shares a high similarity with both the $A$. thaliana (Q8LDC7) and Ricinus communis (XP_002524839.1) protein sequences. The catalytic triad (Cys-78, Asp-126, and His-161) was also identified by comparison with the one from Pseudomonas knackmussii dienalactone hydrolase (PDB: 1DIN) [34]. We could assess the J. curcas protein theoretical $\mathrm{pI}$ and molecular mass as $5.74 \mathrm{kDa}$ and 
22.09 kDa, respectively, using Expasy tools (https:/ / web.expasy.org/compute_pi/) (accessed on 13 January 2021).

\author{
Arabidopsis \\ Jatropha \\ Ricinus
}

\section{Arabidopsis \\ Jatropha \\ Ricinus}

Arabidopsis

Jatropha

Ricinus

Arabidopsis

Jatropha

Ricinus

Arabidopsis

Jatropha

Ricinus

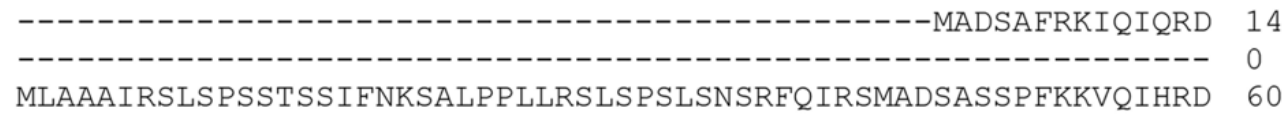

DTTFDAYVVGKDDAPGIVVIQEWWGVDFEIKNHAIKISQLEPGFKALIPDLYRGKVGLDT 74 -----------------MVGVDFE I KNHAVK ISQLEPGYRALIPDLYRGKVGLDV 38 NTTFDAYVIGKDDAPGIVVVQEWWGVDFE IKNHAEKI SQLE PGFKALI PDLYRGKVGLDV 120

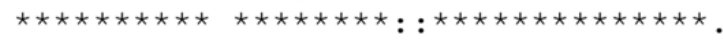

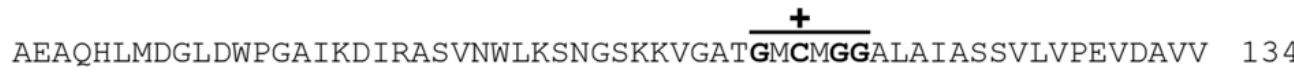
AEAQHLMEDLDWQSVVKDIRASVNWLKANGSKKVGVTGFCMGGALSIASSVLVPEVDAVV 98 AEAQHLMDGLDWQGAVKDIGASVNWLKANGSKKAGVTGFCMGGALAIASSVLVPEVDAVV 180

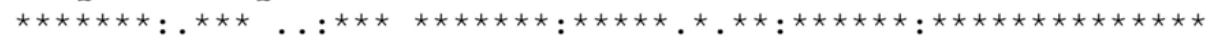

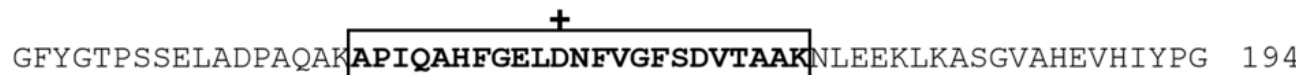
AFYGVPSSELADPAQAKAPIQAHFGELDNEVGFSDVTAAKALEEKLKASGIPYEVHIYPG 158 AFYGVPPSELADATQAKAPIQAHFGELDNFVGFADITAAKALEEKLKASGVPSEVHIYPG 240

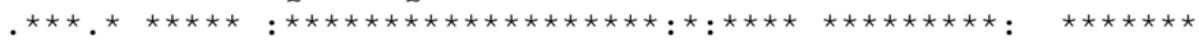
$+$ NGHAFLNRSPEGVSRRKSMGLSDEDEAAVELAWSRFTSWMKQYLA- 239 SAHAFMNRSEEGIKRRKGMGMPDDNEAAAQLAWSRFSSWMGRYLSA 204 NAHAFMNRSAEGVKRRKSMGMPDEDEAAVELAWSRFRSWMNQYLSA 286

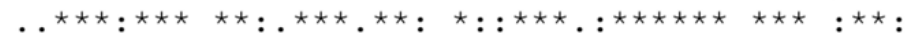

Figure 5. Alignment analysis of A. thaliana carboxymethylenebutenolidase and its homologs in J. curcas and R. communis. Both peptides identified during the mass spectrometry analysis are shown within rectangles. The typical dienalactone hydrolase pentapeptide (GxCxGG) is highlighted, as well as the active site residues Cys-78, Asp-126, and His-161 (marked with +$)$. $\left({ }^{*}\right)$ Conserved sites, (:) sites with conservative replacement, (.) sites with semiconservative replacement.

\subsection{J. curcas L. Esterase B Activity Increases in Basic pH, Corroborating "the Electrostatic Catapult" Model}

To better assess the effect of both temperature and $\mathrm{pH}$ (factors) in the esterase activity (dependent variable, DV), we performed an experimental design (DOE) to obtain the model describing the relationship between these analyzed variables. As seen in Table 3, only temperature, both in linear and quadratic terms, was significant ( $p$-value $<0.05)$ in describing esterase activity variation within the constructed model. Table 4 and Figure 6A show that increasing temperature within the studied range $\left(30\right.$ to $\left.50{ }^{\circ} \mathrm{C}\right)$ had an overall positive effect on the enzymatic activity (model optimum temperature of $48^{\circ} \mathrm{C}$ ). Notwithstanding the non-significance within the model, $\mathrm{pH}$ also affected this dependent variable, as observed in Figure 6B, in which higher activities were detected for more basic buffers ( $\mathrm{pH} 9.0-10.0$ ).

Table 3. Analysis of variance (ANOVA) results for the developed model, correlating esterase activity to reaction temperature and $\mathrm{pH}$.

\begin{tabular}{cccccc}
\hline \multicolumn{5}{c}{ ANOVA; $\mathbf{R}^{\mathbf{2}} \mathbf{\mathbf { 0 . 8 2 2 3 8 }} \mathbf{\text { (2 }}$ Factors with $\mathbf{2}$ Levels Each) } & Central Composite, $\mathbf{n c}=\mathbf{4}, \mathbf{n s}=\mathbf{4}, \mathbf{n} \mathbf{0}=\mathbf{2}$, and Runs = 10) \\
\hline Factor & S.S. & Df & M.S. & F & P \\
\hline (1) Temperature (L) & 0.001857 & 1 & 0.001857 & 11.68790 & 0.014165 \\
Temperature (Q) & 0.001155 & 1 & 0.001155 & 7.26803 & 0.035769 \\
(2) pH (L) & 0.000377 & 1 & 0.000377 & 2.37215 & 0.174446 \\
pH (Q) & 0.000558 & 1 & 0.000558 & 3.51329 & 0.110009 \\
1L by 2L & 0.000730 & 1 & 0.000730 & 4.59470 & 0.075781 \\
Error & 0.000953 & 6 & 0.000159 & & \\
Total SS & 0.005367 & 11 & & & \\
\hline
\end{tabular}


Table 4. Obtained esterase activity values for the conditions analyzed by this experimental design.

\begin{tabular}{ccc}
\hline Temperature $\left({ }^{\circ} \mathbf{C}\right)$ & $\mathbf{p H}$ & Esterase Activity $(\mathbf{U} / \mathbf{m L})$ \\
\hline $33(-1)$ & $7.3(-1)$ & 0.186869 \\
$33(-1)$ & $8.7(+1)$ & 0.183168 \\
$47(+1)$ & $7.3(-1)$ & 0.183168 \\
$47(+1)$ & $8.7(+1)$ & 0.233503 \\
$30(-1.41)$ & $8(0)$ & 0.17268 \\
$50(+1.41)$ & $8(0)$ & 0.225888 \\
$40(0)$ & $7(-1.41)$ & 0.204545 \\
$40(0)$ & $9(+1.41)$ & 0.210396 \\
$40(0)$ & $8(0)$ & 0.202073 \\
$40(0)$ & $8(0)$ & 0.23057 \\
$40(0)$ & $8(0)$ & 0.23057 \\
$40(0)$ & $8(0)$ & 0.227979 \\
\hline
\end{tabular}
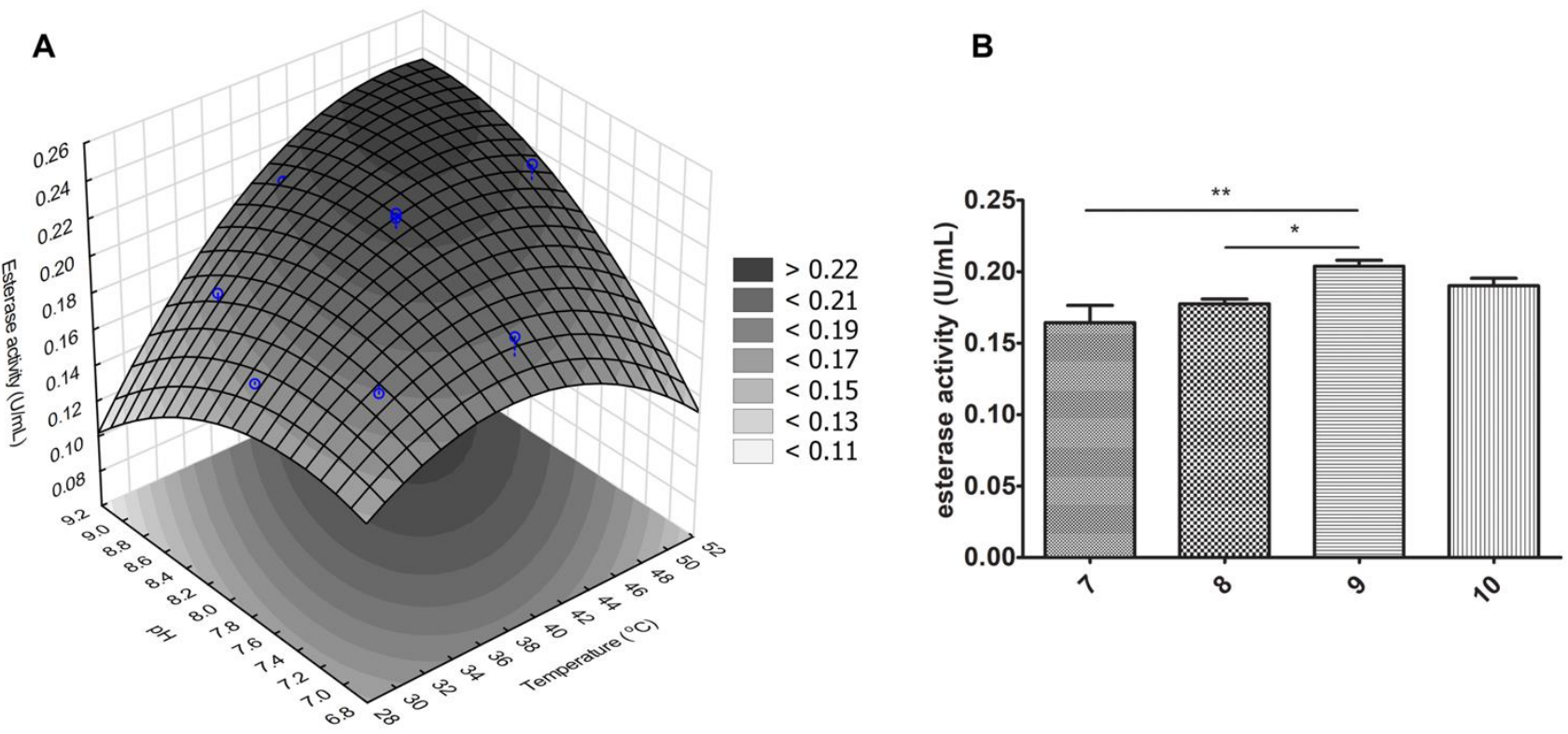

Figure 6. Temperature and $\mathrm{pH}$ effects in esterase activity of J. curcas esterase B. (A) Assessment of their effects were done with a central composite rotational design. Higher esterase activity was observed with higher temperatures and $\mathrm{pH}$ values, as observed in (B). ${ }^{*} p<0.05$ and ${ }^{* *} p<0.01$.

\subsection{Different $p H$ Values Alter the Electrostatic Potential of the J. curcas Esterase B Catalytic Site}

To gain insight into the influence of $\mathrm{pH}$ on the J. curcas esterase catalytic site, we built a tridimensional model based on the crystallographic structure of an uncharacterized protein from Escherichia coli displaying 37\% and 89\% sequence identity and coverage, respectively (Figure 7). The model was refined (method section) and its structural quality was assessed before and after the optimization procedure (Table 5). The optimization helped to improve the quality of the model, making it compatible with the template evaluation. The MolProbity score was better for the refined model than for the template, with values of 0.88 and 0.98 , respectively. A score equal to zero represents the structure having no stereochemical problems. The model's QMEAN had a lower score than the template $(-2.39$ and 0.02 , respectively). However, this value was compatible with high-quality models, making it suitable for subsequent analysis. 


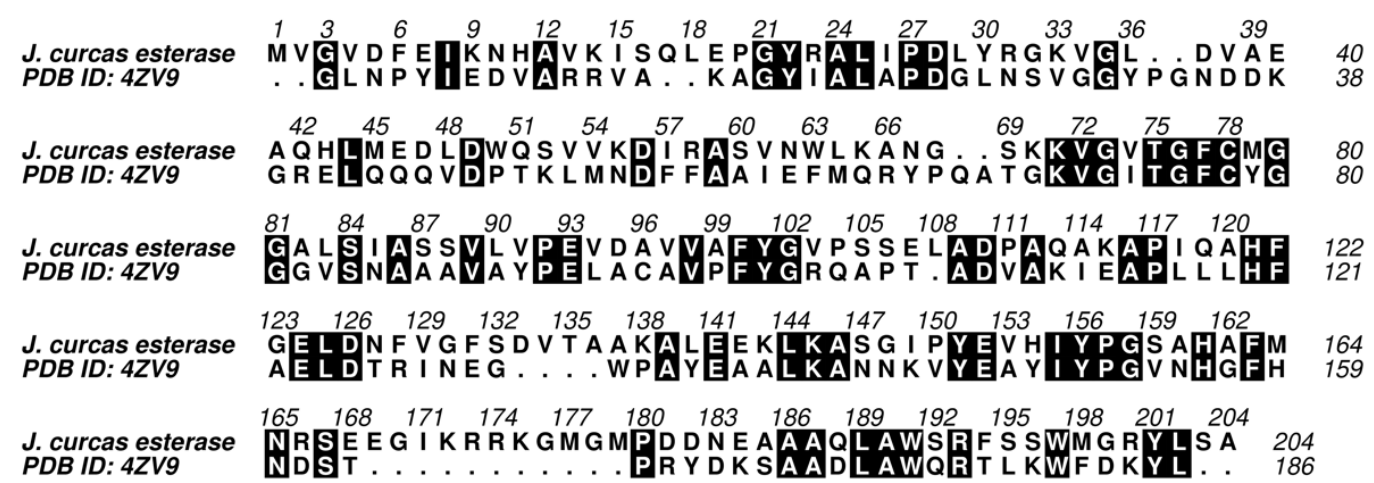

Figure 7. Pairwise sequence alignment employed for the comparative modeling of the $J$. curcas esterase based on the structure of the uncharacterized protein from E. coli O157:H7 str. Sakai (PDB ID: 4ZV9). The sequences have 37\% identity and $89 \%$ coverage. The active site residues-Cys-78, Asp-126, and His-161- are conserved between target and template. Black filled positions in the sequence alignment represent identical residues. Points represent gaps.

Table 5. Evaluation of J. curcas esterase model and its template.

\begin{tabular}{cccc}
\hline Assessment & PDB ID: & Model & $\begin{array}{c}\text { Model } \\
\text { Refined }\end{array}$ \\
\hline MolProbity Score & 0.98 & 1.72 & 0.88 \\
Clash Score & 1.37 & 4.62 & 0.00 \\
Ramachandran Favoured & $97.42 \%$ & $91.92 \%$ & $94.44 \%$ \\
Ramachandran Outliers & $0.00 \%$ & $1.52 \%$ & $0.64 \%$ \\
Rotamer Outliers & $0.54 \%$ & $0.00 \%$ & $0.00 \%$ \\
QMEAN & 0.03 & -2.40 & -2.39 \\
\hline
\end{tabular}

The $\mathrm{pKa}$ values of ionizable groups of $J$. curcas esterase were assessed for $\mathrm{pH}$ values $5.5,8.0$, and 9.5. The $\mathrm{pH}$ influenced the total protein charge with values of $-2.0,-4.0$, and -5.0 for $\mathrm{pH} 5.5,8.0$, and 9.5, respectively. For all $\mathrm{pH}$ values, Cys-78 and Asp-126 of the catalytic triad are neutral and negatively charged, respectively. However, at the acidic $\mathrm{pH}$ of 5.5 , the His-161 of the catalytic site is positively charged, while at both basic $\mathrm{pH}$ values (8.0 and 9.5), histidine is neutral (Figure 8). Other differences were also found in residues more distant from the catalytic triad, such as His- 43 positively charged in acidic $\mathrm{pH}$ and neutral in basic $\mathrm{pH}$ values. Lys-14 is neutral at $\mathrm{pH} 9.5$ and positively charged at $\mathrm{pH} 5.5$ and 8.0 (Figure 8).
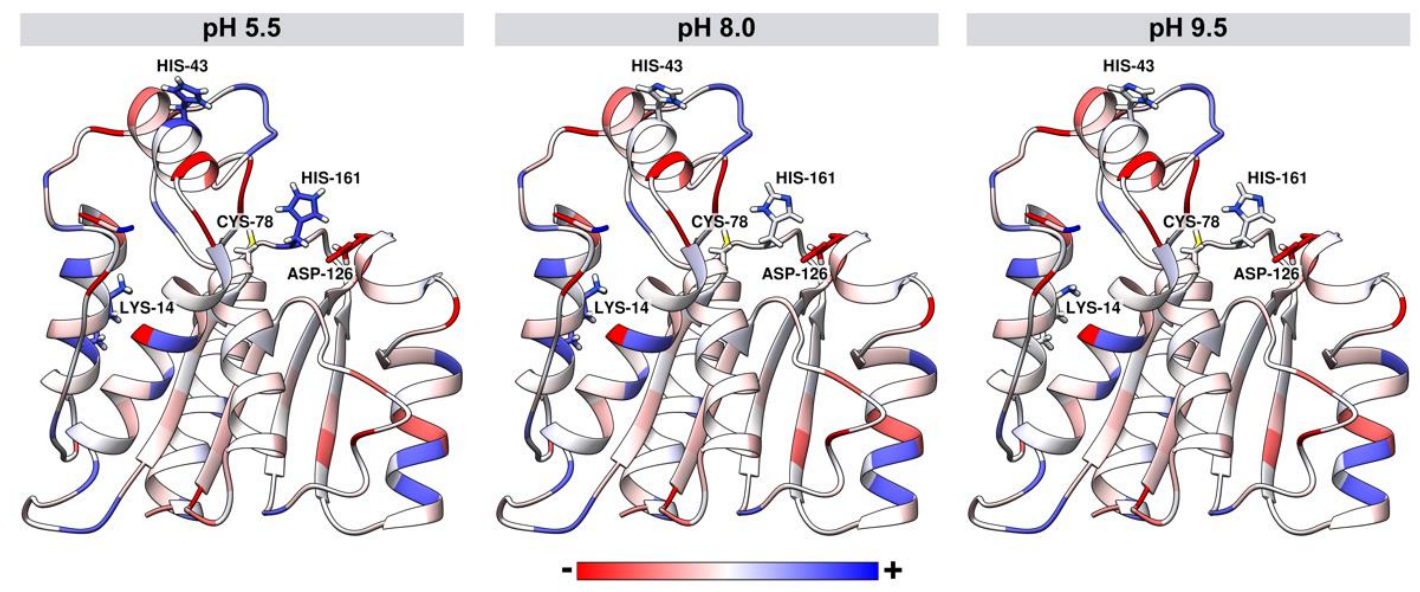

Figure 8. Tridimensional model of J. curcas esterase B developed by comparative modeling. Structures are colored according to the atomic charge for different $\mathrm{pH}$ values: 5.5, 8.0, and 9.5. Sticks represent the catalytic triad residues (Cys-78, Asp-126, and His-161) and the residues that had protonation change according to the $\mathrm{pH}$ values (Lys-14 and His-43). 
His-161 altered the surface of the electrostatic potential in the catalytic triad (Figure 9). At $\mathrm{pH}$ 5.5, positively charged histidine made the site with basic potential. In contrast, the neutral histidine in the basic $\mathrm{pH}$ values left the region with neutral-basic potentials.

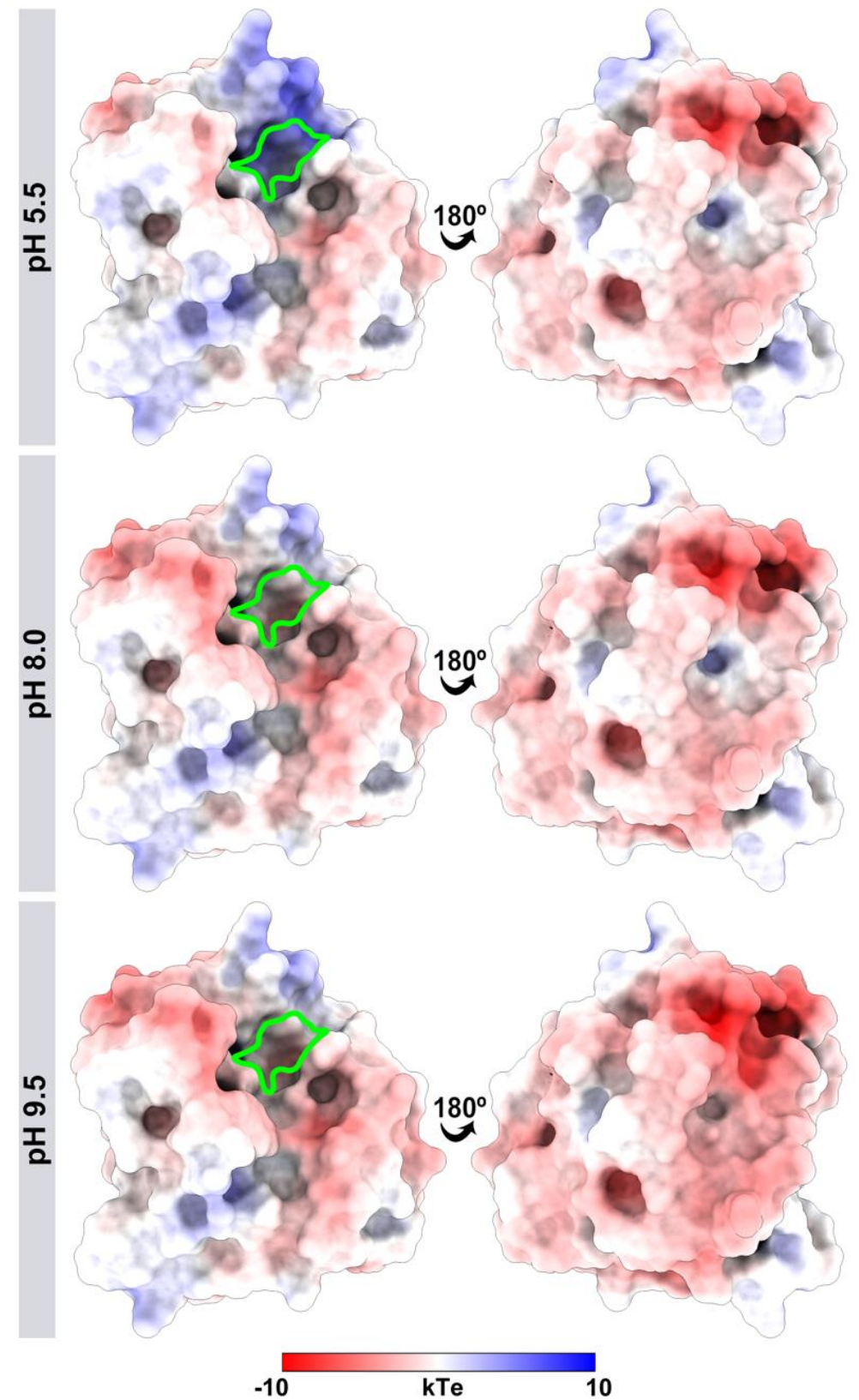

Figure 9. Differences in the electrostatic potential of J. curcas esterase B at different $\mathrm{pH}$ values (5.5, 8.0, and 9.5). The catalytic triad region (Cys-78, Asp-126, and His-161) is highlighted in green. The molecular surface is colored according to the electrostatic potential, where red, white, and blue correspond to acidic, neutral, and basic potentials.

\subsection{J. curcas L. Esterase B Has No Proteolytic Activity and Divalent Ions Inhibit the Enzyme}

We also assessed the peptidase activity for our working sample (EtOH $50-80 \%$ fraction). We used an azocasein assay and also tested esterase activity in the presence of known peptidase inhibitors. In Figure 10, we can observe that there was no detectable peptidase activity and that the inhibitors did not decrease esterase activity. However, when assaying with EDTA, a significant increase in esterase activity was detected, about $160 \%$ of the control sample value. 
A

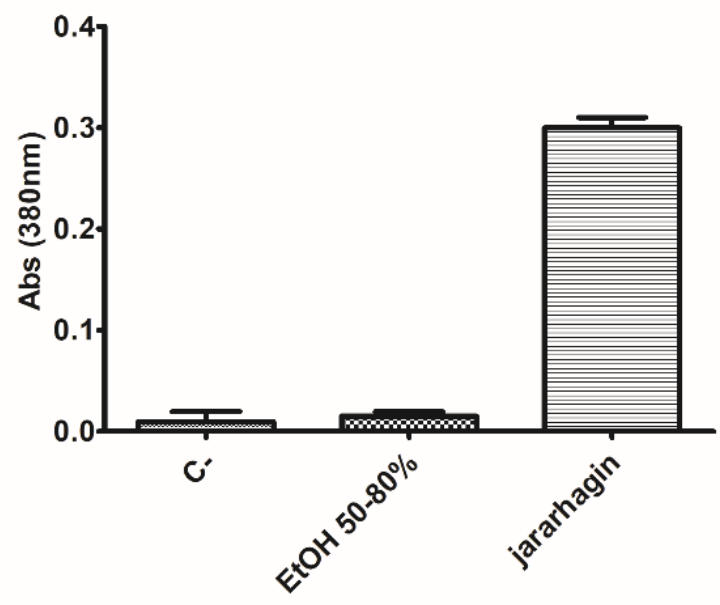

B

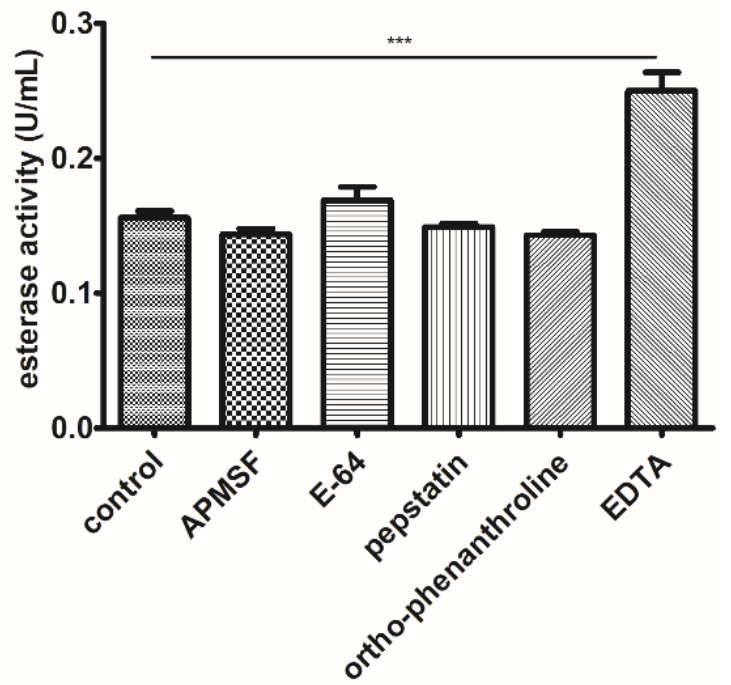

Figure 10. Esterase activity is not due to proteolytic activity. The azocasein assay (A) could not detect significant peptidase activity in the EtOH $50-80 \%$ fraction. (B) Enzymatic analysis in the presence of different peptidase inhibitors corroborated the former finding. Noticeably, the esterase activity of this fraction was enhanced by EDTA addition. ${ }^{* *} p<0.001$.

To further characterize this phenomenon with EDTA, a dose-response experiment was performed. As observed in Figure 11A, an increase in EDTA concentration within the reaction mixture enhanced esterase activity in a dose-response relationship. We also tested activity in the presence of different cations alone and with the EDTA addition. Figure 11B shows that esterase activity was drastically reduced in the presence of several divalent cations (reduction with $\mathrm{Co}^{2+}>\mathrm{Ca}^{2+}>\mathrm{Mg}^{2+}>\mathrm{Ba}^{2+}$ ) and that this could be partially reverted when EDTA was also added.

A

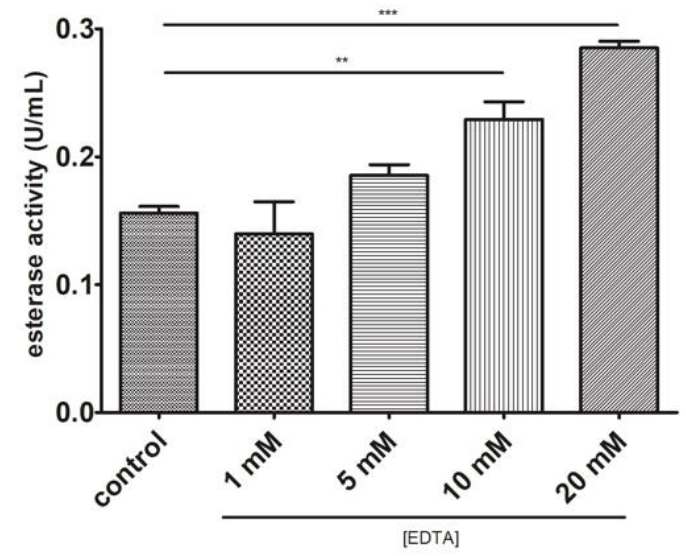

B

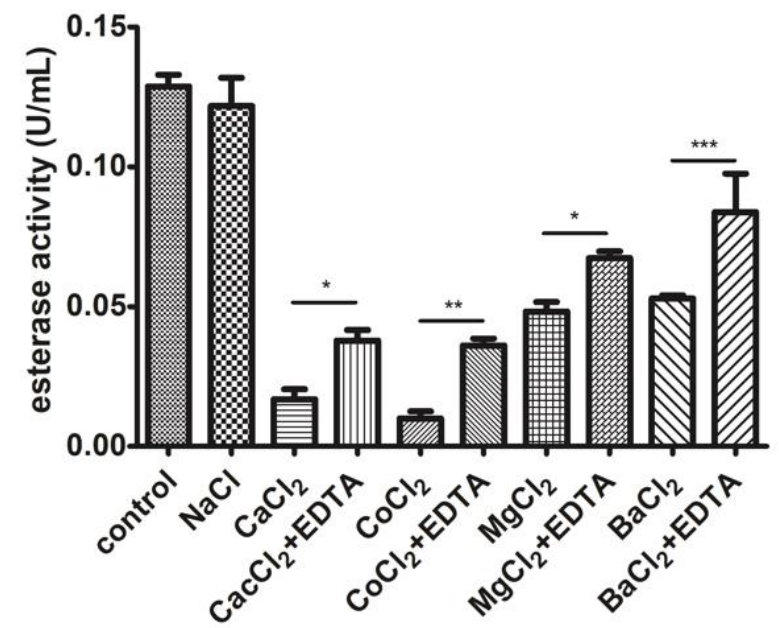

Figure 11. Divalent cations inhibit esterase activity. (A) A dose-response relationship was observed between esterase activity and EDTA. (B) Assaying with different divalent cations corroborated this and the EDTA addition slightly reduced this impact. ${ }^{*} p<0.05,{ }^{* *} p<0.01$, and ${ }^{* * *} p<0.001$. 


\subsection{J. curcas L. Esterase B Has Low Activity in the Presence of Different Solvents}

Esterase activity was assessed in the presence of different organic solvents in the reaction mixture. We have chosen these concentrations to screen different scenarios in which this enzyme could be used as a biocatalyst (low to high organic solvent concentration). For all cases, a severe significant reduction was observed, with a $100 \%$ inhibition for $60 \%$ $(v / v)$ acetonitrile and a $40 \%$ decrease for $10 \%(v / v)$ ethanol, both compared to the control sample (Figure 12A). We also tested the activity after sample incubation with the organic solvent and recovery in an aqueous reaction buffer. In Figure 12B, we observe no significant variation in esterase activity after these treatments compared to the control sample.

A

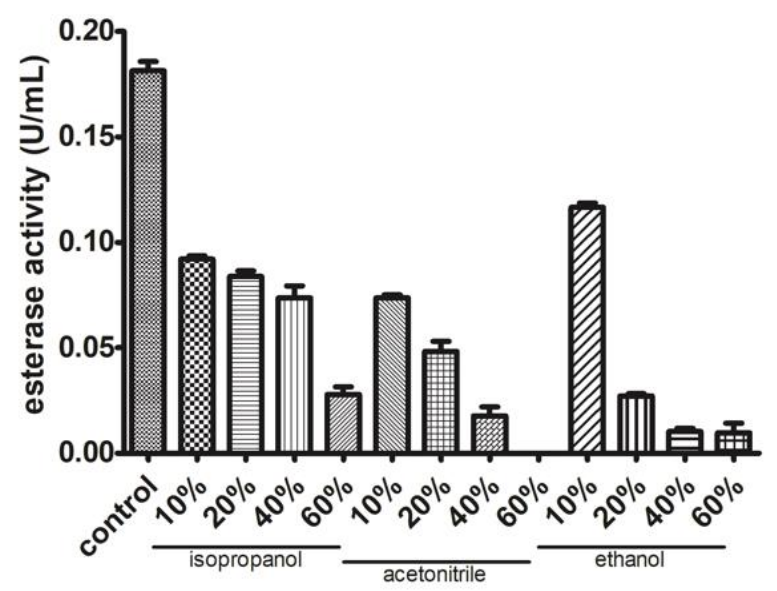

B

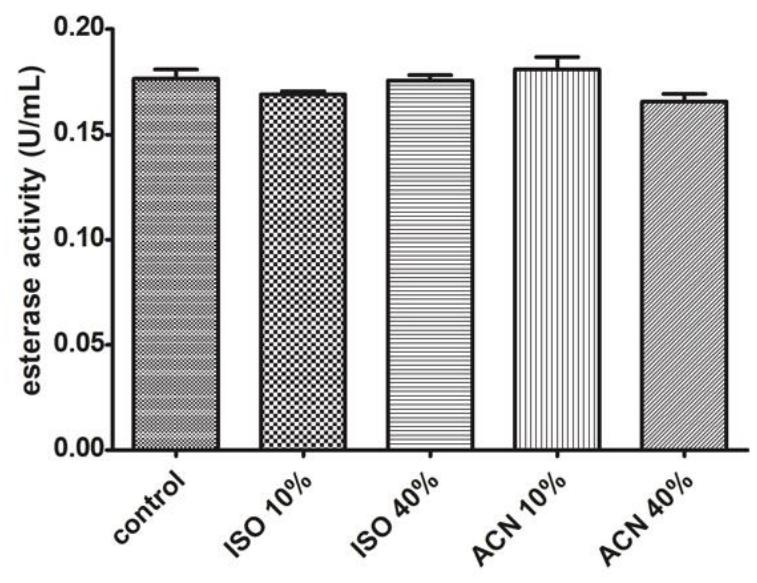

Figure 12. Esterase activity is reversibly lowered in the presence of organic solvents. Esterase activity decreased when isopropanol, acetonitrile, and ethanol were added (A) but sample reconstitution in an aqueous reaction mixture reverses this (B).

\subsection{J. curcas L Esterase B Shows High Hydrolysis Rates but No Enantiospecificity/Selectivity} towards Tested Chiral and Prochiral Substrates

We tested two different substrates to perform an initial assessment of J. curcas L. esterase B potential as a biocatalyst: chiral IPG-octanoate and prochiral diethyl phenylmalonate. For the latter, in all tested reaction times (10 min, $30 \mathrm{~min}, 60 \mathrm{~min}$, and $120 \mathrm{~min})$, we could only detect malonic acid (100\% conversion), indicating a high hydrolysis rate towards the short-chain substrate. Enantiomeric excess values could not be calculated because we could not detect the monoethyl form (the chiral compound that can go through racemic resolution by enantiospecific enzymes).

As shown in Table 6, hydrolysis reaction with IPG-octanoate resulted in lower conversion values than those from diethyl phenylmalonate. Still, once again, the enzyme showed no enantiospecificity toward the tested substrate.

Table 6. Hydrolysis of IPG-octanoate using the $50-80 \%$ EtOH fraction in different reaction time points. $\mathrm{X}$ indicates conversion and ee indicates enantiomeric excess.

\begin{tabular}{cccccc}
\hline \multicolumn{7}{c}{ Time (h) } \\
\hline & \multicolumn{2}{c}{} & \multicolumn{1}{c}{$\mathbf{5}$} \\
\hline & $\mathrm{2}(\%)$ & ee $(\%)$ & $\mathrm{X}(\%)$ & ee $(\%)$ \\
\hline $50-80 \%$ EtOH fraction & 50 & $<0.1$ & 70 & $<0.1$ \\
\hline
\end{tabular}

\section{Discussion}

J. curcas has gained attention from the scientific community due to its high seed oil content, fitted for biodiesel production. Non-toxic J. curcas strains' seeds can be used as an alternative crop for this purpose, leaving press cake as one of the final byproducts. Thus, 
finding destinations and uses for such a material is an essential topic in the research field of $J$. curcas. This species seed has two esterase activities and one of them, esterase B, was previously characterized as a $30 \mathrm{kDa}$ monomeric protein with an optimum hydrolysis $\mathrm{pH}$ of 7.5 and a pI equal to 9.0, in disagreement with the "electrostatic catapult" model for esterases/lipases. To shed light on this apparent discrepancy, as well as to achieve its proper identification, we aimed to study this protein, repeating initial steps as described by [10] and further analyzing its features, mainly regarding its $\mathrm{pI}$ and optimum hydrolysis $\mathrm{pH}$, and how they are consistent, or not, with the "electrostatic catapult" model for esterases/lipases $[17,18]$.

Esterase B was initially described as a $\mathrm{pI} 9.0$ protein [10]. Other reports also reported a carboxylesterase within the J. curcas seed with similar features such as pI, molecular mass, optimum $\mathrm{pH}$, and temperature [11]. Therefore, our purification step after ethanol differential precipitation was an anion exchange chromatography in a $\mathrm{pH} 7.5$ buffer. In this condition, the protein of interest should have a positive net charge and should not bind to the resin, easily eluting in the flow-through fraction. After assessing esterase activity in all chromatographic fractions and performing protein identification by mass spectrometry analysis, we observed that the homogeneous $30 \mathrm{kDa}$ flow-through protein band was curcin, a known seed protein from J. curcas. Curcin is a well-studied $30 \mathrm{kDa}$ basic (pI 9.0) glycoprotein with ribosome-inactivating activity [33] but is less toxic than ricin, an R. communis protein.

Instead of eluting in the flow-through, most of the esterase activity was bound to the resin and eluted in fractions enriched in three protein bands corresponding to malate dehydrogenase, lactoylglutathione lyase, and a putative carboxymethylenebutenolidase (belonging to the DLH family). All these are acidic/neutral polypeptides, with $\mathrm{pI}$ values ranging from 5.0-7.0. These proteins were previously identified in a proteomic characterization study of the J. curcas press cake [7]. Lactoylglutathione lyase and a DLH family protein were thought to be involved in defense and detoxification processes within the seed context. Among these enriched proteins, only DLH is known to have esterase activity, as it also belongs to the $\alpha / \beta$ hydrolase fold group of enzymes $[13,35]$. In the 2D SDS PAGE, this protein was identified in a streak of spots (from $\mathrm{pH}$ 5.0-6.0), indicating different DLH proteoforms in the J. curcas seed with distinct $\mathrm{pI}$ values. Identification of the J. curcas DLH sequence (GenBank accession number KDP24851.1) allowed for the comparison with other plant DLH proteins. This alignment showed a high identity among them, indicating similar functions within natural contexts. Aside from that, the J. curcas DLH theoretical pI and molecular mass of $5.74 \mathrm{kDa}$ and $22.09 \mathrm{kDa}$, respectively, are close to our experimental data. Active site residues' recognition showed a cysteine in the nucleophile position within the catalytic triad; its crucial role was corroborated by activity reduction due to specific cysteine alkylation using iodoacetamide.

Enzymes from the DHL group participate in natural and industrial chloroaromatic compound degradation pathways in bacteria [36]. They have distinctive features among the $\alpha / \beta$-hydrolase fold family such as esterases/lipases. They have a catalytic triad, but instead of serine as a nucleophile, they possess a cysteine, thought to be necessary for substrate-assisted catalysis. In this model, a functional group within the substrate modifies cysteine, activating it and allowing for proper reactions [37]. This mechanism is thought to aid in substrate specificity and in reducing activity loss due to cysteine oxidation. A study with rice seed disulfide proteome, aimed at detecting thioredoxin-linked reactions in seed germination, identified a DLH as a thioredoxin target; this brings the discussion regarding whether in higher plants, another activity control mechanism would be essential to activate the DLH, rather than the substrate-assisted one [8].

After building a tridimensional model for J. curcas DLH, we could assess its electrostatic behavior at different $\mathrm{pH}$ values and the protonation state of titratable residues. We observed that around acidic $\mathrm{pH}$, both the active site and catalytic His-161were positively charged, while the surroundings were near neutral. As $\mathrm{pH}$ increased, the active site and His-161 became neutral while surroundings turned to a negatively charged state. These data corroborated the esterase/lipase "electrostatic catapult" model, which states that such 
enzymes show a higher hydrolytic activity at basic $\mathrm{pH}$ due to the negative surface potential, repelling one of the final reaction products, namely the carboxylic acid (negatively charged in the neutral and basic $\mathrm{pH}$ range) $[17,18]$. Moreover, His-161 charge state in basic $\mathrm{pH}$ allows for proper conditions for the catalytic cycle [38].

The experimental design showed that, within analyzed ranges, the temperature has a more significant impact on esterase activity, but reaction $\mathrm{pH}$ also presents an influence. Once more, this basic optimum $\mathrm{pH}$ corroborates the "electrostatic catapult" model. J. curcas DLH has optimum $\mathrm{pH}$ values and a temperature between 9.0-10.0, and ca. $50^{\circ} \mathrm{C}$. Similar features were associated with other plant esterases such as Cucurbita pepo [39] and Avenua fata [40]. This optimum reaction temperature, along with its molecular mass and monomeric state, is in accordance with previous studies of J. curcas seed esterases $[10,11]$, indicating that they all could be the same enzyme. Conversely, both studies concluded that the esterase had a pI of ca. 9.0, which is not in agreement with our data (pI 5.0-6.0). However, this may have occurred due to curcin contamination in these studies, leading to esterase activity results from $\mathrm{DLH}$, while physicochemical features are derived from the curcin contaminant (same molecular mass). Considering we performed two-dimensional electrophoresis followed by protein identification by mass spectrometry, we could differentiate the $30 \mathrm{kDa}$ esterase from curcin based on their different $\mathrm{pI}$ values.

Due to the active site and catalytic mechanism resemblance among the $\alpha / \beta$ hydrolase family members, it is known that some peptidases can hydrolyze small chain esters [37,41]. Thus, confirming that esterase-detected activity did not derive from a proteolytic activity was an essential step in esterase B characterization. Our results showed no peptidase activity within our working fraction and that peptidase inhibitors did not diminish esterase activity. Moreover, EDTA positively affected esterase activity, indicating that divalent cations inhibit J. curcas DLH, as supported by our other assays with different ions. Similar effects were also observed for other plant esterases/lipases such as C. pepo [39], Glycine max, Oryza sativa [42], and those in wheat flour [43]. Metal ions can affect esterases/lipases and other $\alpha / \beta$ hydrolases activity by different mechanisms such as by coordinating with active site residues [44], overall structure alteration by allosteric regulation [44,45], surface potential alteration (a pH-dependent event) [46], and reaction equilibrium dislocation through low-soluble salt production with one of the hydrolysis reaction products, namely the carboxylic acid (mainly described for $\mathrm{Ca}^{2+}[47]$ ). Whether it is an activation or inhibition scenario depends on each enzyme-metal ion pair and this activity alteration usually represents a gain or loss of enzyme stability. Thus, further experiments should be performed to assess the actual mechanism for J. curcas DLH divalent cation inhibition, exploring these distinct possible scenarios both by activity assays and in silico analysis.

Finally, we performed preliminary assays to assess the J. curcas DLH potential in hydrolysis reactions of industrial interest, focusing on producing enantiomerically pure compounds. Our results showed that this enzyme was not enantiospecific/selective towards the tested substrates (solketal ester [IPG-octanoate] and diethyl phenyl malonate, a prochiral compound) but it had high conversion rates. For instance, in the same period and conditions for which Amano AK, a Pseudomonas fluorecens lipase, had a conversion rate of about $10 \%$ (with product enantiomeric excess $>99 \%$ ) when using a racemic solketal ester in a hydrolysis reaction [24], J. curcas DLH had conversion values of 50\% (but with enantiomeric excess $<5 \%$ ). Therefore, our initial analysis indicates that this catalyst has high hydrolytic activity. Further studies should be done to analyze this enzyme's use in specific reactions in chemical processes. Additionally, recombinant enzyme production might be interesting to obtain a highly homogeneous bioproduct without contaminants derived from the J. curcas seed, such as curcin.

\section{Conclusions}

This work shows that J. curcas seed esterase could be useful when short-chain ester hydrolysis is desired. Our data from the two-dimensional electrophoresis approach and structural analysis after comparative modeling indicate that this enzyme is indeed in 
agreement with the esterases/lipases' "electrostatic catapult" model and that the previously described $\mathrm{pI}$ value was probably from curcin, contaminating the esterase working sample, as these proteins have a similar molecular mass. Aside from that, mass spectrometry analysis identified the enzyme as belonging to the dienelactone hydrolase class, which harbors a cysteine as the nucleophile within the catalytic triad. These data are corroborated by activity inhibition when adding iodoacetamide, an alkylating reagent. Furthermore, activity maintenance after organic solvent incubation (isopropanol and acetonitrile) could be an interesting feature, allowing for the use of these compounds during purification steps such as in reversed-phase chromatography. However, the general use of J. curcas DLH is still impaired by its inhibition by divalent cations and its low activity in the presence of organic solvents (isopropanol, acetonitrile, and ethanol). Aside from that, as a final remark, developing new uses for the J. curcas press cake and using it as an enzyme source is essential to develop this crop research field, aggregating the value for the biodiesel production with this plant oil and stimulating this research field.

Author Contributions: Conceptualization, M.G.A.S., R.H.V. and D.M.G.F.; methodology, M.G.A.S. and D.A.; validation, M.G.A.S., D.A. and G.C.B.; formal analysis, M.G.A.S., R.H.V., D.M.G.F., D.A. and G.C.B.; investigation, M.G.A.S. and D.A.; resources, R.H.V. and D.M.G.F.; writing-original draft preparation, M.G.A.S. and D.A.; writing-review and editing, G.C.B., R.H.V. and D.M.G.F; funding acquisition, R.H.V. All authors have read and agreed to the published version of the manuscript.

Funding: Richard H. Valente is a fellow from Conselho Nacional de Desenvolvimento Científico e Tecnológico (CNPq), grant number 304523/2019-4.

Institutional Review Board Statement: Not applicable.

Informed Consent Statement: Not applicable.

Data Availability Statement: The data presented in this study are available within the manuscript.

Acknowledgments: The authors thank the Fiocruz Network of Technology Platforms for the use of their core facilities (Proteômica/RJ RPT2A Espectrometria de massas).

Conflicts of Interest: The authors declare no conflict of interest.

\section{References}

1. Maghuly, F.; Laimer, M. Jatropha curcas, a Biofuel Crop: Functional Genomics for Understanding Metabolic Pathways and Genetic Improvement. Biotechnol. J. 2013, 8, 1172-1182. [CrossRef]

2. Ewunie, G.A.; Morken, J.; Lekang, O.I.; Yigezu, Z.D. Factors Affecting the Potential of Jatropha Curcas for Sustainable Biodiesel Production: A Critical Review. Renew. Sustain. Energy Rev. 2021, 137, 110500. [CrossRef]

3. Abobatta, W.F. Jatropha curcas, a Novel Crop for Developing the Marginal Lands. In Biofuels and Biodiesel, 1st ed.; Basu, C., Ed.; Springer Nature: New York, NY, USA; Humana Press: New York, NY, USA, 2021; pp. 79-100.

4. Halmemies-Beauchet-Filleau, A.; Rinne, M.; Lamminen, M.; Mapato, C.; Ampapon, T.; Wanapat, M.; Vanhatalo, A. Review: Alternative and Novel Feeds for Ruminants: Nutritive Value, Product Quality and Environmental Aspects. Animal 2018, 12, s295-s309. [CrossRef] [PubMed]

5. Gomes, T.G.; Hadi, S.I.I.A.; Costa Alves, G.S.; Mendonça, S.; de Siqueira, F.G.; Miller, R.N.G. Current Strategies for the Detoxification of Jatropha curcas Seed Cake: A Review. J. Agric. Food Chem. 2018, 66, 2510-2522. [CrossRef] [PubMed]

6. de Sousa, J.S.; Cavalcanti-Oliveira, E.d.; Aranda, D.A.G.; Freire, D.M.G. Application of Lipase from the Physic Nut (Jatropha curcas L.) to a New Hybrid (Enzyme/Chemical) Hydroesterification Process for Biodiesel Production. J. Mol. Catal. B Enzym. 2010, 65, 133-137. [CrossRef]

7. León-Villanueva, A.; Huerta-Ocampo, J.A.; Barrera-Pacheco, A.; Medina-Godoy, S.; Barba de la Rosa, A.P. Proteomic Analysis of Non-Toxic Jatropha Curcas Byproduct Cake: Fractionation and Identification of the Major Components. Ind. Crop. Prod. 2018, 111, 694-704. [CrossRef]

8. Yano, H.; Kuroda, M. Disulfide Proteome Yields a Detailed Understanding of Redox Regulations: A Model Study of ThioredoxinLinked Reactions in Seed Germination. Proteomics 2006, 6, 294-300. [CrossRef]

9. Urs, A.P.; Rudresha, G.V.; Manjuprasanna, V.N.; Suvilesh, K.N.; Gowda, M.D.M.; Yariswamy, M.; Hiremath, V.; Ramakrishnan, C.; Savitha, M.N.; Jayachandra, K.; et al. Plant Latex Thrombin-like Cysteine Proteases Alleviates Bleeding by Bypassing Factor VIII in Murine Model. J. Cell. Biochem. 2019, 120, 12843-12858. [CrossRef]

10. Staubmann, R.; Ncube, I.; Gübitz, G.M.; Steiner, W.; Read, J.S. Esterase and Lipase Activity in Jatropha curcas L. Seeds. J. Biotechnol. 1999, 75, 117-126. [CrossRef] 
11. Subramani, T.; Chandrashekharaiah, K.S.; Swamy, N.R.; Murthy, K.R.S. Purification and Characterization of Carboxylesterase from the Seeds of Jatropha Curcas. Protein J. 2012, 31, 120-128. [CrossRef]

12. Nanssou Kouteu, P.A.; Baréa, B.; Barouh, N.; Blin, J.; Villeneuve, P. Lipase Activity of Tropical Oilseed Plants for Ethyl Biodiesel Synthesis and Their Typo- and Regioselectivity. J. Agric. Food Chem. 2016, 64, 8838-8847. [CrossRef]

13. Chen, Y.; Black, D.S.; Reilly, P.J. Carboxylic Ester Hydrolases: Classification and Database Derived from Their Primary, Secondary, and Tertiary Structures. Protein Sci. 2016, 25, 1942-1953. [CrossRef] [PubMed]

14. Casas-Godoy, L.; Gasteazoro, F.; Duquesne, S.; Bordes, F.; Marty, A.; Sandoval, G. Lipases: An Overview. In Lipases and Phospholipases, 2nd ed.; Sandoval, G., Ed.; Springer Nature: New York, NY, USA; Humana Press: New York, NY, USA, 2018; pp. 3-38.

15. Bracco, P.; van Midden, N.; Arango, E.; Torrelo, G.; Ferrario, V.; Gardossi, L.; Hanefeld, U. Bacillus Subtilis Lipase A-Lipase or Esterase? Catalysts 2020, 10, 308. [CrossRef]

16. Carvalho, A.; Fonseca, T.; Mattos, M.; Oliveira, M.; Lemos, T.; Molinari, F.; Romano, D.; Serra, I. Recent Advances in LipaseMediated Preparation of Pharmaceuticals and Their Intermediates. Int. J. Mol. Sci. 2015, 16, 29682-29716. [CrossRef] [PubMed]

17. Neves Petersen, M.T.; Fojan, P.; Petersen, S.B. How Do Lipases and Esterases Work: The Electrostatic Contribution. J. Biotechnol. 2001, 85, 115-147. [CrossRef]

18. Neves-Petersen, M.T.; Petersen, E.I.; Fojan, P.; Noronha, M.; Madsen, R.G.; Petersen, S.B. Engineering the PH-Optimum of a Triglyceride Lipase: From Predictions Based on Electrostatic Computations to Experimental Results. J. Biotechnol. 2001, 87, 225-254. [CrossRef]

19. Moura-da-Silva, A.M.; Baldo, C. Jararhagin, a Hemorrhagic Snake Venom Metalloproteinase from Bothrops Jararaca. Toxicon 2012, 60, 280-289. [CrossRef] [PubMed]

20. LAEMMLI, U.K. Cleavage of Structural Proteins during the Assembly of the Head of Bacteriophage T4. Nature 1970, 227, 680-685. [CrossRef]

21. Rabilloud, T.; Charmont, S. Proteome Research: Two-Dimensional Gel Electrophoresis and Identification Methods; Rabilloud, T., Ed.; Springer: Berlin/Heidelberg, Germany, 2000; ISBN 978-3-540-65792-7.

22. Shevchenko, A.; Wilm, M.; Vorm, O.; Mann, M. Mass Spectrometric Sequencing of Proteins from Silver-Stained Polyacrylamide Gels. Anal. Chem. 1996, 68, 850-858. [CrossRef] [PubMed]

23. Gharahdaghi, F.; Weinberg, C.R.; Meagher, D.A.; Imai, B.S.; Mische, S.M. Mass Spectrometric Identification of Proteins from SilverStained Polyacrylamide Gel: A Method for the Removal of Silver Ions to Enhance Sensitivity. Electrophoresis 1999, $20,601-605$. [CrossRef]

24. Machado, A.C.O.; da Silva, A.A.T.; Borges, C.P.; Simas, A.B.C.; Freire, D.M.G. Kinetic Resolution of (R,S)-1,2-Isopropylidene Glycerol (Solketal) Ester Derivatives by Lipases. J. Mol. Catal. B Enzym. 2011, 69, 42-46. [CrossRef]

25. Manoel, E.A.; Ribeiro, M.F.P.; dos Santos, J.C.S.; Coelho, M.A.Z.; Simas, A.B.C.; Fernandez-Lafuente, R.; Freire, D.M.G. Accurel MP 1000 as a Support for the Immobilization of Lipase from Burkholderia cepacia: Application to the Kinetic Resolution of myo-Inositol Derivatives. Process Biochem. 2015, 50, 1557-1564. [CrossRef]

26. Waterhouse, A.; Bertoni, M.; Bienert, S.; Studer, G.; Tauriello, G.; Gumienny, R.; Heer, F.T.; de Beer, T.A.P.; Rempfer, C.; Bordoli, L.; et al. SWISS-MODEL: Homology Modelling of Protein Structures and Complexes. Nucleic Acids Res. 2018, 46, W296-W303. [CrossRef]

27. Feig, M. Local Protein Structure Refinement via Molecular Dynamics Simulations with LocPREFMD. J. Chem. Inf. Model. 2016, 56, 1304-1312. [CrossRef]

28. Bond, C.S.; Schüttelkopf, A.W. ALINE: A WYSIWYG Protein-Sequence Alignment Editor for Publication-Quality Alignments. Acta Crystallogr. Sect. D Biol. Crystallogr. 2009, 65, 510-512. [CrossRef] [PubMed]

29. Pettersen, E.F.; Goddard, T.D.; Huang, C.C.; Couch, G.S.; Greenblatt, D.M.; Meng, E.C.; Ferrin, T.E. UCSF Chimera-A Visualization System for Exploratory Research and Analysis. J. Comput. Chem. 2004, 25, 1605-1612. [CrossRef]

30. Goddard, T.D.; Huang, C.C.; Meng, E.C.; Pettersen, E.F.; Couch, G.S.; Morris, J.H.; Ferrin, T.E. UCSF ChimeraX: Meeting Modern Challenges in Visualization and Analysis. Protein Sci. 2018, 27, 14-25. [CrossRef] [PubMed]

31. Baker, N.A.; Sept, D.; Joseph, S.; Holst, M.J.; McCammon, J.A. Electrostatics of Nanosystems: Application to Microtubules and the Ribosome. Proc. Natl. Acad. Sci. USA 2001, 98, 10037-10041. [CrossRef] [PubMed]

32. Dolinsky, T.J.; Nielsen, J.E.; McCammon, J.A.; Baker, N.A. PDB2PQR: An Automated Pipeline for the Setup of Poisson-Boltzmann Electrostatics Calculations. Nucleic Acids Res. 2004, 32, W665-W667. [CrossRef] [PubMed]

33. Zhang, Y.; Yang, Q.; Li, C.; Ding, M.; Lv, X.; Tao, C.; Yu, H.; Chen, F.; Xu, Y. Curcin C, a Novel Type I Ribosome-Inactivating Protein from the Post-Germinating Cotyledons of Jatropha curcas. Amino Acids 2017, 49, 1619-1631. [CrossRef] [PubMed]

34. Pathak, D.; Ollis, D. Refined Structure of Dienelactone Hydrolase at 1.8A ${ }^{\circ}$. J. Mol. Biol. 1990, 214, 497-525. [CrossRef]

35. Porter, J.L.; Carr, P.D.; Collyer, C.A.; Ollis, D.L. Crystallization of Dienelactone Hydrolase in Two Space Groups: Structural Changes Caused by Crystal Packing. Acta Crystallogr. Sect. F Struct. Biol. Commun. 2014, 70, 884-889. [CrossRef] [PubMed]

36. Kumar, A.; Pillay, B.; Olaniran, A.O. Two Structurally Different Dienelactone Hydrolases (TfdEI and TfdEII) from Cupriavidus Necator JMP134 Plasmid PJP4 Catalyse Cis- and Trans-Dienelactones with Similar Efficiency. PLoS ONE 2014, 9 , e101801. [CrossRef] [PubMed]

37. Holmquist, M. Alpha Beta-Hydrolase Fold Enzymes Structures, Functions and Mechanisms. Curr. Protein Pept. Sci. 2000, 1, 209-235. [CrossRef] 
38. Walker, I.; Hennessy, J.E.; Ollis, D.L.; Easton, C.J. Substrate-Induced Conformational Change and Isomerase Activity of Dienelactone Hydrolase and Its Site-Specific Mutants. ChemBioChem 2012, 13, 1645-1651. [CrossRef] [PubMed]

39. Fahmy, A.S.; Abo-Zeid, A.Z.; Mohamed, T.M.; Ghanem, H.M.; Borai, I.H.; Mohamed, S.A. Characterization of Esterases from Cucurbita pepo Cv. "Eskandrani.". Bioresour. Technol. 2008, 99, 437-443. [CrossRef] [PubMed]

40. Mohamed, M.A.; Mohamed, T.M.; Mohamed, S.A.; Fahmy, A.S. Distribution of Lipases in the Gramineae. Partial Purification and Characterization of Esterase from Avena Fatua. Bioresour. Technol. 2000, 73, 227-234. [CrossRef]

41. Hedstrom, L. Serine Protease Mechanism and Specificity. Chem. Rev. 2002, 102, 4501-4524. [CrossRef]

42. Seth, S.; Chakravorty, D.; Dubey, V.K.; Patra, S. An Insight into Plant Lipase Research-Challenges Encountered. Protein Expr. Purif. 2014, 95, 13-21. [CrossRef]

43. Hou, C.; He, K.; Yang, L.; Huo, D.; Yang, M.; Huang, S.; Zhang, L.; Shen, C. Catalytic Characteristics of Plant-Esterase from Wheat Flour. World J. Microbiol. Biotechnol. 2012, 28, 541-548. [CrossRef]

44. Eron, S.J.; MacPherson, D.J.; Dagbay, K.B.; Hardy, J.A. Multiple Mechanisms of Zinc-Mediated Inhibition for the Apoptotic Caspases-3, -6, -7, and -8. ACS Chem. Biol. 2018, 13, 1279-1290. [CrossRef]

45. Bowles, I.E.; Pool, E.H.; Lancaster, B.S.; Lawson, E.K.; Savas, C.P.; Kartje, Z.J.; Severinac, L.; Cho, D.H.; Macbeth, M.R.; Johnson, R.J.; et al. Transition Metal Cation Inhibition of Mycobacterium tuberculosis Esterase RV0045C. Protein Sci. 2021, 30, 1554-1565. [CrossRef] [PubMed]

46. Hertadi, R.; Widhyastuti, H. Effect of $\mathrm{Ca}^{2+}$ Ion to the Activity and Stability of Lipase Isolated from Chromohalobacter japonicus BK-AB18. Procedia Chem. 2015, 16, 306-313. [CrossRef]

47. García-Cano, I.; Rocha-Mendoza, D.; Kosmerl, E.; Jiménez-Flores, R. Purification and Characterization of a PhospholipidHydrolyzing Phosphoesterase Produced by Pediococcus acidilactici Isolated from Gouda Cheese. J. Dairy Sci. 2020, 103, $3912-3923$. [CrossRef] [PubMed] 